\title{
Canopy Exchange and Modification of Nitrogen Fluxes in Forest Ecosystems
}

\author{
Rossella Guerrieri ${ }^{1}$ (D) $\cdot$ Pamela Templer $^{2} \cdot$ Federico Magnani $^{1}$
}

Accepted: 15 April 2021 / Published online: 24 August 2021

(C) The Author(s) 2021

\begin{abstract}
Purpose of Review We provide an overview of the main processes occurring during the interactions between atmospheric nitrogen and forest canopies, by bringing together what we have learned in recent decades, identifying knowledge gaps, and how they can be addressed with future research thanks to new technologies and approaches.

Recent Findings There is mounting evidence that tree canopies retain a significant percentage of incoming atmospheric nitrogen, a process involving not only foliage, but also branches, microbes, and epiphytes (and their associated micro-environments). A number of studies have demonstrated that some of the retained nitrogen can be assimilated by foliage, but more studies are needed to better quantify its contribution to plant metabolism and how these fluxes vary across different forest types. By merging different approaches (e.g., next-generation sequence analyzes and stable isotopes, particularly oxygen isotope ratios) it is now possible to unveil the highly diverse microbial communities hidden in forest canopies and their ability to process atmospheric nitrogen through processes such as nitrification and nitrogen fixation. Future work should address the contribution of both foliar nitrogen uptake and biological transformations within forest canopies to whole ecosystem nitrogen cycling budgets.

Summary Scientists have studied for decades the role of forest canopies in altering nitrogen derived from atmospheric inputs before they reach the forest floor, showing that tree canopies are not just passive filters for precipitation water and dissolved nutrients. We now have the technological capability to go beyond an understanding of tree canopy itself to better elucidate its role as sink or source of nutrients, as well as the epiphytes and microbial communities hidden within them.
\end{abstract}

Keywords Nitrogen fluxes · Nitrogen deposition · Forest canopy $\cdot$ Stable isotopes $\cdot$ Phyllosphere $\cdot$ Epiphytes $\cdot$ Nitrogen retention $\cdot$ Nitrogen assimilation $\cdot$ Nitrification $\cdot$ Nitrogen fixation $\cdot$ Soil canopy $\cdot$ Microbes

\section{Introduction}

Earth's climate is significantly affected by the continuous exchange of water, carbon dioxide $\left(\mathrm{CO}_{2}\right)$, and energy between forests and the atmosphere. Tree canopies remove about $30 \%$ of the atmospheric dioxide $\left(\mathrm{CO}_{2}\right)$ emitted by anthropogenic activities through photosynthesis. This removal contributes to the terrestrial $\mathrm{CO}_{2}$ sink, which has doubled over the last

This article is part of the Topical Collection on Physiological Processes

Rossella Guerrieri

r.guerrieri@unibo.it

1 DISTAL, Alma Mater Studiorum, University of Bologna, Via Fanin 46, I-40127 Bologna, Italy

2 Boston University, Department of Biology, 5 Cummington Mall, Boston, MA 02215, USA decade compared to the 1960 s, from $1.3 \pm 0.4$ Gigaton $(\mathrm{Gt}) \mathrm{C}$ year $^{-1}$ to $3.4 \pm 0.9 \mathrm{Gt} \mathrm{C}$ year $^{-1}$ during 2009-2018 [1]. Through stomata on foliar surfaces, water moves from the soil to the atmosphere during transpiration, a process intrinsically associated with $\mathrm{CO}_{2}$ uptake and that plays a key role in hydrological cycling. It is estimated that about $40 \%$ of incident precipitation around the globe is returned back to the atmosphere through transpiration by forest canopies [2]. Transpiration through tree canopies can feedback to climate by cooling the air through latent heat flux or through contributions to cloud formation and reductions in incoming solar radiation. However, forest canopies can also lead to warming through their relatively low albedo and release of water vapor, a potent greenhouse gas [3].

Water and carbon dioxide, however, are not the only compounds that tree canopies exchange with the atmosphere. Indeed, canopies are continuously exposed to chemical compounds emitted into the atmosphere by natural and 
anthropogenic activities and deposited back to the biosphere as wet and dry deposition (ref. chapter 2). Among them, nitrogen in atmospheric deposition has received a lot of attention over the last several decades because of its role in affecting carbon, nitrogen, and water cycling. A positive relationship exists between rates of nitrogen deposition and leaf [4-6*•] or canopy [7] photosynthesis, tree growth [8,9], and water-use efficiency [10-12], due to nitrogen availability strongly affecting all of these processes. Elevated rates of nitrogen deposition has been recognized as one of the drivers contributing to enhanced forest carbon sequestration (and hence a form of climate change mitigation), particularly for nitrogen limited ecosystems in temperate and boreal biomes [13-17]. Greater nitrogen content in tree canopies due to an increase in atmospheric nitrogen input can also feedback to climate by increasing albedo ( [18] - positive feedback) and evapotranspiration ( [19] - negative feedback).

Increases in atmospheric nitrogen deposition can also accelerate rates of nitrogen cycling, leading to a cascade of effects [20] that eventually shifts the balance between accumulation to nitrogen loss pathways, increases in eutrophication of nearby waterways, loss of diversity [21-23], and nutrient imbalances, such as phosphorus and cations [24]. The influence of tree canopies in nitrogen cycling has been often assessed in terms of litter production and decomposition, the latter playing a crucial role in soil biogeochemical processes [25]. Yet, tree canopies - and the overlooked life hidden within them (e.g., epiphytes and microbial communities) - can retain, assimilate, and process atmospheric nitrogen, thus changing the quantity (in terms of fluxes) and quality (in terms of nitrogen forms) of atmospheric nitrogen inputs eventually reaching the forest floor and soils beneath. However, the mechanisms underlying these differences between what goes into, through, and out of forest canopies are still debated.

Here, we provide a comprehensive overview of how tree canopies contribute to nitrogen cycling, by bringing together knowledge scientists have learned over the last several decades from a variety of research and methodological approaches (i.e., manipulation experiments vs. observations along environmental gradients), and scales, going from the whole ecosystem (e.g., quantification of forest nitrogen fluxes) to canopies (e.g., investigation of foliar nitrogen uptake) down to genes (with omic techniques, and gene-specific quantitative PCR; qPCR). We begin by providing a general introduction to atmospheric nitrogen deposition, focusing mostly on inorganic nitrogen. We then describe what happens when atmospheric nitrogen interacts with tree canopies and the life hidden within them, elucidating three processes: retention, assimilation, and biological transformation (Fig. 1). Last, we identify knowledge gaps and how they can be addressed with future research.

\section{Quantifying and Monitoring Atmospheric Nitrogen Deposition}

Concentrations of reactive inorganic nitrogen $(\mathrm{N})$ compounds in the atmosphere, i.e., reduced forms $\left(\mathrm{NH}_{3}, \mathrm{NH}_{4}{ }^{+}\right)$and oxidized forms ( $\mathrm{NO}, \mathrm{NO}_{2}, \mathrm{NO}_{3}^{-}, \mathrm{HNO}_{3}$, and $\mathrm{N}_{2} \mathrm{O}$ ), have increased by 10 -fold since 1860 , from 15 to 156 Teragram (Tg) $\mathrm{N}$ year ${ }^{-1}$ in the early $1990 \mathrm{~s}$ and to $210 \mathrm{Tg} \mathrm{N}$ year $^{-1}$. Asia, North America, and Europe are hotspots for these atmospheric nitrogen inputs [26, 27]. In particular, $\mathrm{N}_{2} \mathrm{O}$ emissions have increased by more than $20 \%$ (from 270 parts per billion (ppb) in 1750 to $331 \mathrm{ppb}$ in 2018), which has positive feedbacks to climate change since it is a greenhouse gas [28]. Intensive agriculture (including livestock) for food production that has sustained human growth is responsible for about $85 \%$ of global $\mathrm{NH}_{3}$ emissions [29] and for more than $70 \%$ of global $\mathrm{N}_{2} \mathrm{O}$ emissions [28]. Galloway and Cowing [20] estimated that only a limited amount of the applied fertilizer is recovered in the produced food, and that 80 and $90 \%$ of the supplied nitrogen in agricultural systems to grow plants for food production or to feed livestock for meat production is either recycled in the agroforestry systems or lost to the environment (through $\mathrm{NO}_{3}^{-}$leaching, denitrification, or $\mathrm{NH}_{3}$ volatilization). Emissions from power plants and road transport are the main sources of the increase in oxidized nitrogen compounds to the atmosphere [30]. Some components of reactive nitrogen enter terrestrial and aquatic ecosystems as wet (dissolved in precipitation or fog) and dry (as gaseous processes and particles) deposition.

Regional networks have been established worldwide, with the aim of in-situ monitoring of air quality, including changes in reactive nitrogen concentrations and fluxes. These include the European Monitoring and Evaluation Program (EMEP), the National Atmospheric Deposition Program (NADP), and Clean Air Status and Trends Network (CASTNET) in the USA (with the NADP/National Trends Network (NTN) extending to Canada, and Mexico), the Canadian Air and Precipitation Monitoring Network (CAPMoN) in Canada, the Nationwide Nitrogen Deposition Monitoring Network (NNDMN) operated by China Agricultural University, and the Acid Deposition monitoring network (EANET) in East Asia. In Africa, monitoring of wet and dry deposition started in the late 1990's at 10 sites in the west and central parts of the continent, within the IDAF (International Global Atmospheric Chemistry (IGAC)/Deposition of Biogeochemically Important Trace Species (DEBITS)/Africa), which is still active at 3 sites [31••]. To gain a more detailed spatial understanding of trends in deposition and their effects on natural ecosystems, intensive monitoring networks have been established in forests across Europe, such as the International Co-operative Program on Assessment and Monitoring of Air Pollution Effects on Forests (ICP Forests), which has been active since in 1995. 
Fig. 1. Overview of the main processes underpinning the interactions between tree canopies and atmospheric nitrogen deposition. Numbers refer to processes we describe in the text: 1 - retention of nitrogen deposition by tree canopies and epiphytes; 2 - foliar nitrogen uptake; 3- leaching of dry nitrogen deposition and dissolved organic nitrogen; 4- microbial nitrogen transformations (e.g., nitrogen fixation, nitrification). Light blue and yellow circles indicate wet and dry nitrogen deposition, respectively. Illustration describing process 1was modified from Gotsch et al. (2017)

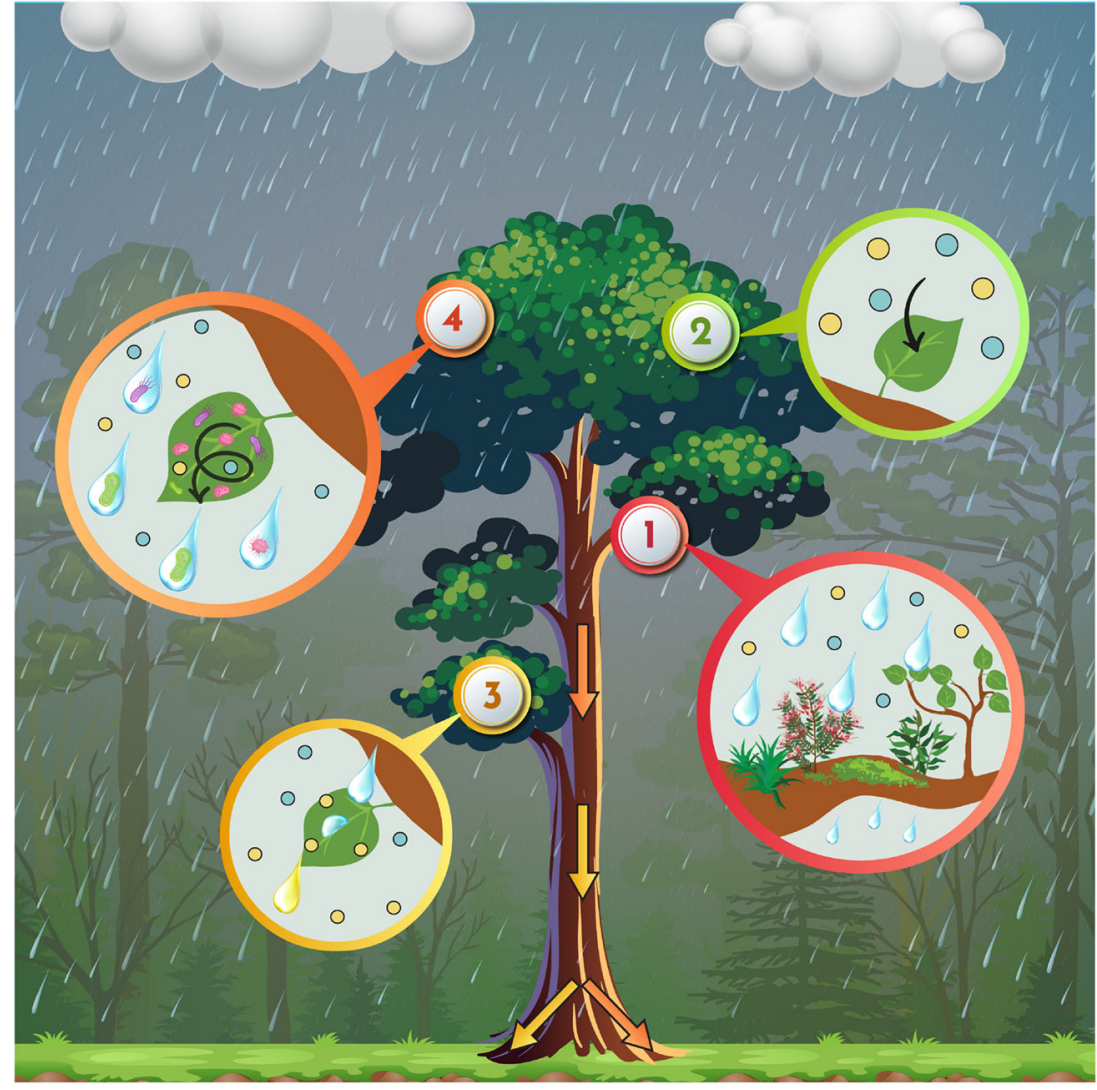

Quantification of inorganic atmospheric nitrogen deposition fluxes is carried out by measuring $\mathrm{NH}_{4}{ }^{+}$and $\mathrm{NO}_{3}{ }^{-}$concentrations in water collected in the open areas outside the forest (i.e., wet only or bulk deposition) and beneath tree canopies (i.e., throughfall deposition, Fig. 2A), which are then used in conjunction with measurements of precipitation volume to calculate fluxes. Collectors for bulk and wet deposition are placed in an open space, outside the forest, so to collect the total atmospheric nitrogen deposition (mostly as wet deposition). However, some of the dry nitrogen compounds can also be deposited in bulk collectors, unless wet-only collectors are installed, which are equipped with a lid that closes during dry periods and only open during precipitation events. These approaches have allowed researchers to document how wet nitrogen deposition has changed over the last decades across Europe and North America [32, 33] and also to identify hotspots such as areas where critical loads have been reached in natural [34] or urban [35••, 36•] ecosystems.
Fig. 2. Monitoring of nitrogen deposition in forests by using throughfall water collectors (panel A) and ion exchange resins, IER (panel B). Photo in the panel A refers to an oak forest within the ICP forest network in Europe (i.e., Alice Holt forest in the UK), while in the panel $\mathbf{B}$ we show a close-up photo of the ion exchange resin collector. Photos were taken by Rossella Guerrieri (panel A) and Pamela Templer (panel B).
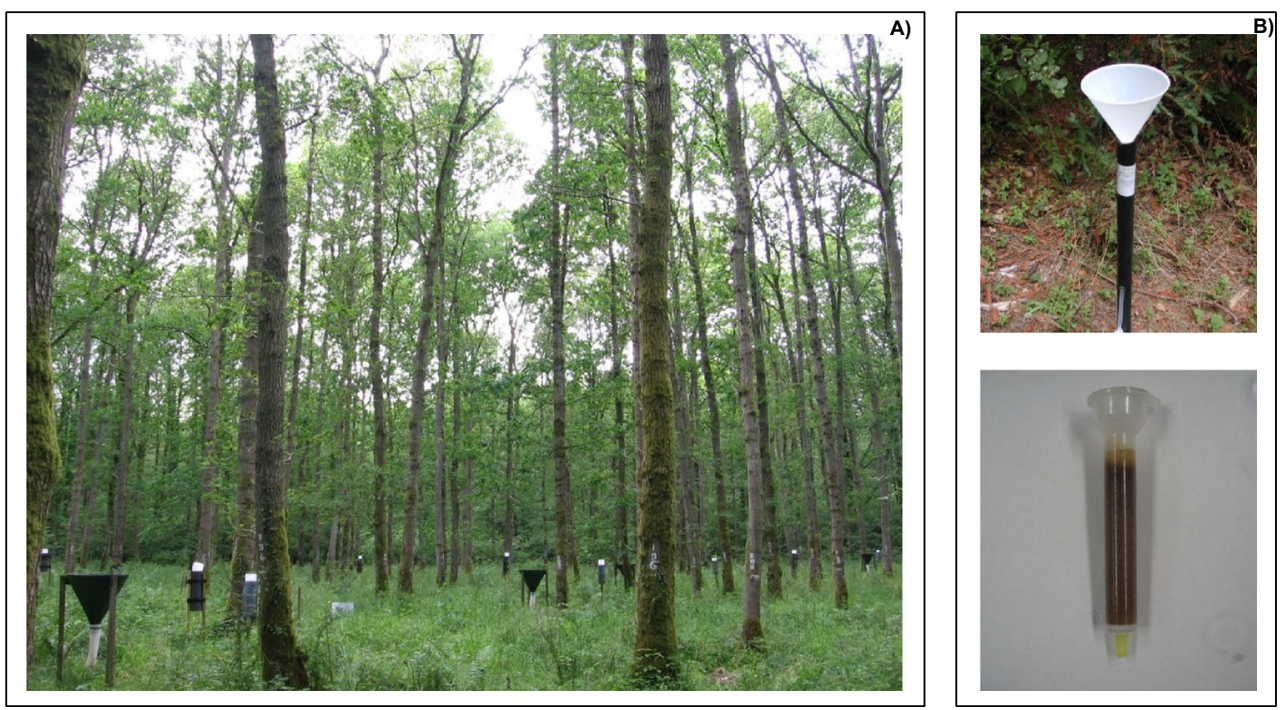
Another approach widely used in the USA (see e.g., [37, 38]Fig. 2B) and recently in Europe [39••] and China [40], is to incubate mixed ion (i.e. cation plus anion) exchange resins in the field for several weeks at a time. Ion exchange resin (IER) columns can be placed in open areas (outside the forest) to measure bulk deposition or beneath the canopy to measure throughfall, which as in the case of classical water throughfall collectors, provide estimates of wet plus dry deposition since particulates settle on leaves and get washed into collectors when there is precipitation ( [41] and reference therein). A number of studies showed that quantification of nitrogen deposition fluxes based on the IER method was comparable to that obtained from traditional water collection [37, 39, 41]. The advantage of using the IER method is that it allows for greater site replication since it requires fewer sampling times compared to the traditional approach that requires weekly collections. However, it has been shown that the IER approach could overestimate $\mathrm{NH}_{4}-\mathrm{N}$ deposition, due to the release of $\mathrm{NH}_{4}{ }^{+}$from the amine compounds from the anion exchange resin polymer, but it could underestimate $\mathrm{NH}_{4}-\mathrm{N}$ deposition during heavy rain events. We recommend that readers read relevant studies by Fenn and Poth [37], García-Gomez et al. [39], and Fenn et al. [41] for more details on the limitations of the IER approach, as well as recommendations to improve quantification of inorganic nitrogen deposition with this approach.

One limitation of the estimates from national networks is that they do not provide a clear picture of total nitrogen deposition on a given area, given the difficulties of quantifying reactive dry nitrogen compounds in the atmosphere (and hence their deposition), which has been shown to be an important proportion of total nitrogen deposition [42-45]. Compared to wet $\mathrm{N}$ deposition, quantifying dry $\mathrm{N}$ deposition is still challenging due to the lack of intensive dry deposition monitoring networks, the difficulties of measuring reactive nitrogen compounds, and the challenge of including deposition processes in models [46]. A very simplistic approach used to estimate dry nitrogen deposition is to calculate the difference in nitrogen fluxes between throughfall and bulk deposition [48.]. Because of their roughness and high turbulence, tree canopies are efficient at absorbing or scavenging reactive nitrogen from the atmosphere [49]. The deposited reactive nitrogen is then washed off during a rain event so that water collected in throughfall reflects both wet and dry reactive nitrogen. This approach, however, has a number of limitations, which will be discussed later (cf. chapters 3 and 5).

A number of networks have been established to monitor gaseous reactive nitrogen, with particular focus on ammonia-see e.g., Ammonia Monitoring Network $(\mathrm{AMoN})$ in the USA (in addition to CASTNET, where gas and particulate air concentrations of $\mathrm{HNO}_{3}, \mathrm{NH}_{4}{ }^{+}$aerosol, and $\mathrm{NO}_{3}{ }^{-}$aerosol are included), the Ammonia Monitoring Network in China (AMoN-China), and a number of initiatives in the European Continent (Measuring Ammonia in Nature network, MAN in the Netherlands or National Ammonia Monitoring Network, NAMN in the UK, and the European Monitoring and Evaluation Program, EMEP, across Europe).

Estimating dry nitrogen deposition is more complex than what we described already for wet deposition and involves measurements and modeling approaches. At the monitoring sites where concentrations of gaseous nitrogen compounds are measured (commonly with passive samplers, filter packs, denuders $[41,47,50])$, dry deposition can be estimated by using inferential modeling approach, which consider the deposition velocities of a given compound in relation to the landuse and the vegetation type, but also canopy conductance [46, 51]. Dry deposition can also be estimated by considering the differences in ion concentrations between bulk vs. throughfall water fluxes in the so-called canopy budget model ( [52], ref. chapter 4). A number of studies from the early 2000s have shown the great potential of micrometeorological approaches, such as the eddy covariance technique (EC), to estimate reactive nitrogen fluxes directly (e.g., [53, 54] for $\mathrm{NH}_{3}$, [55] for $\mathrm{NO}_{\mathrm{y}}$, [56] for total reactive nitrogen, [45] for a review of its application in the USA). Its applicability, though, is challenged by the very sophisticated instruments required, as well as the high reactivity of dry nitrogen compounds [56].

In-situ monitoring (either via sampling of gaseous concentrations or EC flux measurements) are often spaced apart and are typically located in rural areas to gain regional understanding of atmospheric deposition trends, but still they are limited in number to capture other processes related to transport of dry nitrogen forms [57]. The limited spatial coverage of groundbased dry nitrogen deposition monitoring can be overcome by considering inventory emissions (such as the Emissions Database for Global Atmospheric Research, EDGAR, led by the Joint Research Center in Europe [58]) and atmospheric remote sensing. A number of satellite-based monitoring of surface pollutants have been established (NASA Aura Ozone Monitoring Instrument, ESA Tropospheric Ozone Monitoring Instrument, TROPOMI - see [59] for a review, [60]), representing an important advance to fill the data gap for gaseous nitrogen compounds. Estimates of dry nitrogen deposition at the regional or global scale (either considering ground-based or inventory emissions and satellite-derived nitrogen concentrations) rely on modeling approaches, such as chemical transport models, e.g., EMEP MSC-W [46, 57], LOTUS-EUROS [61], and GEOS-CHEM (http://acmg.seas. harvard.edu/geos/). We refer readers to the studies by Theobald et al. [62] for a comparison among different chemical transport models, and by Dentener et al. 2006 [63] and Vet et al. 2014 [64] as example of estimates of atmospheric nitrogen deposition based on an ensemble of chemistry transport models. Since our goal in this chapter is to provide an overview of the approaches at different scales to estimate reactive nitrogen emissions and deposition, we refer readers to Liu et al. [65•] for a review of recent advances about 
estimating surface reactive nitrogen concentration and deposition using satellite-based methods and the main challenges associated with these approaches.

Although this literature review mostly focuses on inorganic reactive $\mathrm{N}$, it is important to point out that while monitoring of inorganic nitrogen deposition has intensified over the past decades, this is not the case for organic nitrogen deposition. Measuring concentrations or fluxes of organic nitrogen in deposition is challenging as it is commonly done through the difference between the total nitrogen (i.e. organic + inorganic) and inorganic nitrogen in deposition, which can be labor intensive and expensive [66-68 $]$. The contribution of organic nitrogen forms has been estimated to be on average between $30 \%$ and $50 \%$ of the total nitrogen deposition based on nitrogen fluxes measurements at 27 locations worldwide [69] or across Europe $[66,67]$ - with the percentage as high as $70 \%$ in the Mediterranean basin [70]. This result suggests that not accounting for organic nitrogen deposition leads to an underestimation of total nitrogen deposition and its contribution to nitrogen cycling $[26,71]$.

Human activities have increased atmospheric nitrogen inputs to terrestrial ecosystems by $46 \mathrm{Tg} \mathrm{N}$ year ${ }^{-1}$ compared to pre-industrial time [72], with recent global estimates ranging between 90 [73] and $100 \mathrm{Tg} \mathrm{N}_{\text {year }}{ }^{-1}$ [64, 71], with hotspots in eastern Asia, Europe, eastern North America, and southern Brazil [72]. Of the total $\mathrm{N}$ deposition, $70 \mathrm{Tg} \mathrm{N}$ year ${ }^{-1}$ are deposited onto terrestrial surfaces [27], with about $18 \mathrm{Tg} \mathrm{N}$ year ${ }^{-1}$ reaching forest ecosystems [72].

Results from long-term monitoring networks reported a significant reduction in nitrogen (particularly the oxidized forms) and sulfur deposition (e.g., [32, 45] in Europe and North America; [33] based on measurements at the European ICP Forests) over the last several decades. Rates of total nitrogen deposition are generally elevated in urban compared to nearby rural areas [74•]. However, decreases over time were steeper for sulfur compared to nitrogen deposition, particularly in the case of $\mathrm{NH}_{3}$ deposition [43, 48•]. A recent study by Fenn and colleagues [75] highlighted that onroad emissions of $\mathrm{NH}_{3}$ have increased in the USA due to the introduction of vehicles equipped with new engine technologies, where aqueous urea is injected as a reductant for $\mathrm{NO}_{\mathrm{x}}$ control, leading to the production of $\mathrm{NH}_{3}[76,77]$. Actions for abatement of $\mathrm{NH}_{3}$ emissions and hence, deposition are more difficult to put in place, given their link to food production [78]. In contrast to North America and Europe, China has experienced an overall increase in nitrogen deposition over recent decades [79]. Moreover, global estimates from satellite-based observations and modeling highlighted the increase in nitrogen deposition in tropical regions [26, 63, 73], due to the intensification of agriculture (and hence increasing use of synthetic fertilizers) and biomass burning associated with deforestation $[80,81]$.

\section{Tree Canopies and Nitrogen Fluxes: What Comes in From the Atmosphere does not Always Reach Soils Beneath}

Where does atmospheric nitrogen go when moving through forest ecosystems and how does atmospheric nitrogen deposition affect processes occurring within tree canopies? Three approaches have been used to answer this question: nitrogen manipulation experiments (either on seedlings or on mature trees in forests), observations across sites within long-term nitrogen monitoring networks, and individual observational studies. We summarize all three below.

To follow the fate and activity of atmospherically deposited nitrogen to forest ecosystems, nitrogen is often added in amounts and forms that mimic atmospheric deposition, mostly as ammonium nitrate $\left(\mathrm{NH}_{4} \mathrm{NO}_{3}\right.$; with labeled ${ }^{15} \mathrm{~N}$ fertilizer in some cases to track specific cohorts of nitrogen throughout an ecosystem). Past studies, mostly considering soil nitrogen fertilizations, showed that soil and not trees retain most of the nitrogen that comes from atmospheric deposition (e.g., Emmett et al. [82], presenting results from the manipulation experiments within NITREX project across European temperate and boreal forests; Nadelhoffer et al. [83], for results on the longterm soil manipulation experiment at Harvard forest in the USA; Gurmesa et al. [84], in a humid tropical forest in China; Schlesinger [72] and Templer et al. [85] for two analyses across many studies). Moreover, from soil fertilization experiments researchers found that the simulated increase in nitrogen deposition had a significant effect on the biogeochemical processes, leading to soil acidification, increases in $\mathrm{NO}_{3}{ }^{-}$leaching and nutrient imbalances [86-89], and shifts in bacterial [90] and/or fungal communities [91].

Tree canopies are critical to our understanding of the nitrogen cycle since they can modify the amount and form of nitrogen entering the forest floor through retention, transformation, and absorption by foliage, a process often excluded in previous soil manipulation experiments. Some past and more recently established studies have mimicked the increase in nitrogen deposition using mist applications directly to tree canopies in forests or at the watershed scale (ref. Table 1) to investigate the effects of increasing nitrogen deposition on nitrogen cycling at the whole ecosystem scale. Among those experiments, however, only a few have specifically elucidated the interactions between atmospheric nitrogen deposition and tree canopies, whose results will be discussed in this chapter. The first canopy nitrogen addition experiment we are aware of was carried out on a young Sitka spruce plantation at Deepsyke in Scotland (UK). The experiment included nitrogen misting over tree canopies alone or in combination with sulfur as single or double dose (48 
Table 1 Overview of the experimental sites where nitrogen applications to forest canopies have been carried out. We also include experiments that are no longer active and describe when experimental treatments also include nitrogen applications to soil and the level of ambient atmospheric nitrogen deposition $\left(\mathrm{N}_{\mathrm{dep}}\right)$. $\mathrm{CN}$ and $\mathrm{CNS}$ indicates canopy nitrogen and canopy nitrogen + sulfur aerial misting, respectively, whereas SN indicates soil nitrogen applications. Numbers following $\mathrm{CN}, \mathrm{CNS}$ or SN indicate that different doses where applied, for a given treatment. ( $\left.{ }^{*}\right)$ Values was calculated as half of the dose applied, as Adams et al. (2007) reported additions of $\mathrm{N}$ and $\mathrm{S}$ are approximately twice the ambient nitrogen deposition in the adjacent watershed considered as control

\begin{tabular}{|c|c|c|c|c|c|c|}
\hline $\begin{array}{l}\text { Name o the site } \\
\text { (Region, Country) }\end{array}$ & Forest type (dominant tree species) & Forest age & $\begin{array}{l}\text { Ambient } N_{\text {dep }} \\
\left(\mathrm{kg} \mathrm{ha}^{-1} \text { year }^{-1}\right)\end{array}$ & $\begin{array}{l}\mathrm{N} \text { dose applied } \\
\left(\mathrm{kg} \mathrm{ha}^{-1} \text { year }^{-1}\right)\end{array}$ & Duration & Reference \\
\hline $\begin{array}{l}\text { Deepsyke (Scotland, } \\
\text { UK) }\end{array}$ & $\begin{array}{l}\text { Conifer forest (Picea sitchensis } \\
\text { (Bong.) Carr.) }\end{array}$ & 30 & $8-10$ & $\begin{array}{l}\text { CN: } 48 \\
\text { CNS1: } 48 \\
\text { CNS2: } 96\end{array}$ & $1996-2003$ & $\begin{array}{l}\text { Sheppard et al. 2004; } \\
\text { [92] Guerrieri et al. } \\
2011 \text { [10] }\end{array}$ \\
\hline $\begin{array}{l}\text { Howland forest (Maine, } \\
\text { USA) }\end{array}$ & $\begin{array}{l}\text { Conifer forest (Picea rubens Sarg, } \\
\text { Tsuga canadensis (L.) Carr.) }\end{array}$ & $\sim 140$ & $<5$ & 18 & $2001-2005$ & $\begin{array}{l}\text { Gaige et al. 2007; Dail } \\
\text { et al. } 2009[93,94]\end{array}$ \\
\hline $\begin{array}{l}\text { Cansiglio (Veneto, } \\
\text { Italy) }\end{array}$ & $\begin{array}{l}\text { Deciduous forest (Fagus } \\
\text { sylvatica L.) }\end{array}$ & $\sim 140$ & 20 & $\begin{array}{l}\text { CN: } 30 \\
\text { SN1: } 30 \\
\text { SN2: } 60\end{array}$ & 2015-present & - \\
\hline $\begin{array}{l}\text { Cembra (Trentino Alto } \\
\text { Adige, Italy) }\end{array}$ & $\begin{array}{l}\text { Deciduous forest (Fagus } \\
\text { sylvatica } \mathrm{L} \text {.) }\end{array}$ & 60 & $<10$ & $\mathrm{CN}: 20$ & 2018-present & - \\
\hline $\begin{array}{r}\text { Monticolo (Trentino } \\
\text { Alto Adige, Italy) }\end{array}$ & $\begin{array}{l}\text { Deciduous forest (Quercus } \\
\text { petrea } \mathrm{L} .)\end{array}$ & 67 & 6.6 & $\mathrm{CN}: 20$ & 2015-present & $\begin{array}{l}\text { Giammarchi et al. } 2020 \\
\text { [95] }\end{array}$ \\
\hline $\begin{array}{l}\text { Jigongshan National } \\
\text { Natural Reserve } \\
\text { (Henan, China) }\end{array}$ & $\begin{array}{l}\text { Mixed deciduous forest (Quercus } \\
\text { acutissima Carruth, Quercus } \\
\text { variabilis } \mathrm{Bl} \text {., Liquidambar } \\
\text { formosana Hance) }\end{array}$ & 45 & 19.6 & $\begin{array}{l}\text { CN1: } 25 \\
\text { CN2: } 50\end{array}$ & 2013-present & Zhang et al. 2015 [96•] \\
\hline $\begin{array}{l}\text { Shimentai National } \\
\text { Natural Reserve } \\
\text { (Guangdong, China) }\end{array}$ & $\begin{array}{l}\text { Broadleaved evergreen forest } \\
\text { (Cryptocarya concinna, Schima } \\
\text { superba, Machilus chinensis, } \\
\text { Castanea henryi (Skan) Rehd, } \\
\text { Engelhardtia roxburghiana) }\end{array}$ & 50 & 34.1 & $\begin{array}{l}\text { SN1: } 25 \\
\text { SN2: } 50\end{array}$ & 2013-present & Zhang et al. 2015 [96•] \\
\hline $\begin{array}{l}\text { Bear Brook (Eastern } \\
\text { Maine, USA) }\end{array}$ & $\begin{array}{l}\text { Mixed deciduous forest with some } \\
\text { conifers at high elevation }\end{array}$ & $50-80$ & 8.4 & $\begin{array}{l}\text { CN: } 25.2 \\
\text { CNS: } 28.8\end{array}$ & $1989-2016$ & $\begin{array}{l}\text { Fernandez et al. } 2003 \\
\quad[97]\end{array}$ \\
\hline $\begin{array}{l}\text { Fernow (West Virginia, } \\
\text { USA) }\end{array}$ & Mixed deciduous forest & $34-95$ & $17.5^{*}$ & $\begin{array}{l}\text { CN: } 35.5 \\
\text { CNS: } 40.5\end{array}$ & 1989- & Adams et al. 2007 [98] \\
\hline $\begin{array}{l}\text { Monts-Valin and } \\
\text { Simoncouche } \\
\text { (Quebec, Canada) }\end{array}$ & $\begin{array}{l}\text { Conifer forest } \\
\text { (Picea mariana (Mill.) BSP) }\end{array}$ & 80 & $0.7-1$ & $\mathrm{CN}: 2$ & 2008-2016 & $\begin{array}{l}\text { De Barba et al. } 2016 \\
\text { [99] }\end{array}$ \\
\hline $\begin{array}{l}\text { Prades (Cataluña, } \\
\text { Spain) }\end{array}$ & Evergreen forest (Quercus ilex L.) & 80 & 15 & $\mathrm{CN}: 60$ & 2015-present & - \\
\hline
\end{tabular}

and $96 \mathrm{~kg} \mathrm{ha}^{-1} \mathrm{year}^{-1}$ for both nitrogen and sulfur) for 5-8 years so to simulate an increase in acid deposition (cf. [92, 100]). Another remarkable manipulation experiment was carried out at Howland in Maine (USA), where an increase in nitrogen deposition over a mature spruce-fir forest was simulated by water drop though a helicopter for 5 years (Table 1). Both experiments showed that between 20-40\% (at Deepsyke Forest [101, 102]) and up to $70 \%$ (at Howland Forest [93]) of the applied nitrogen remained in tree canopies. A similar percentage of nitrogen canopy retention (30-50\%) was reported in a recently established (and still active) manipulation experiment in an evergreen broad-leaved forest [6] and mixed deciduous forest [103] in China at the two forest sites described in Table 1. Different dynamics of canopy nitrogen exchange were observed at Deepsyke Forest according to whether the nitrogen addition also contained sulfur. In fact, the absolute amount of nitrogen retained as $\mathrm{NH}_{4}{ }^{+}$and $\mathrm{NO}_{3}{ }^{-}$ was similar regardless of the applied doses (i.e., $40 \%$ for both), whereas tree canopies in the nitrogen addition treatment retained more $\mathrm{NH}_{4}{ }^{+}$(i.e., $60 \%$ ) than $\mathrm{NO}_{3}^{-}$(i.e., $8 \%$ ) [102]. The preferential higher retention of $\mathrm{NH}_{4}^{+}$vs. $\mathrm{NO}_{3}{ }^{-}$ by tree canopies was also found at Howland Forest. Moreover, at Howland, by carrying out a ${ }^{15} \mathrm{~N}$ tracer 
experiment (i.e., spraying trace amounts of enriched ${ }^{15} \mathrm{~N}$ $\mathrm{NH}_{4}$ and ${ }^{15} \mathrm{~N}-\mathrm{NO}_{3}$ on subplots) researchers tracked the fate of nitrogen, including foliage, wood, and bark. Surprisingly, the highest ${ }^{15} \mathrm{~N}$ retention was observed in branches and bark and not in foliage, as expected. This result suggests that the high retention within the ecosystem was more related to physico-chemical interactions between atmospheric nitrogen and plant surfaces rather direct uptake through foliage [94••]. However, another important result from the manipulation experiment at Howland forest was the rapid conversion of $\mathrm{NH}_{4}{ }^{+}$and $\mathrm{NO}_{3}{ }^{-}$into soluble organic nitrogen in tree canopies, which led to an increase in below-canopy dissolved organic nitrogen fluxes [93]. This result was explained by the authors as rapid assimilation of inorganic nitrogen by plants and associated epiphytes, and consequent release as plant, lichen, and microbial exudates, via physical damage to foliage, or via insect mediated release [93]. An increase in organic nitrogen fluxes below- canopies was also detected at Deepsyke Forest but its contribution to total nitrogen fluxes was smaller compared to what was observed at Howland forest, indicating a limited capacity to generate organic nitrogen within the canopy for this ecosystem [104].

A comparison of tree-ring stable nitrogen isotopic composition $\left(\delta^{15} \mathrm{~N}\right.$ - ref. Appendix 1) (evaluated as difference between nitrogen addition treatment and control-no ${ }^{15} \mathrm{~N}$ labeling was applied-Fig. 3, modified from Guerrieri et al. [10]) between canopy and soil nitrogen fertilization experiments showed a different pattern between the two approaches considered in terms of ecosystem nitrogen dynamics. With increasing nitrogen dose applied to the soil, the natural abundance $\delta^{15} \mathrm{~N}$ values in tree rings became more ${ }^{15} \mathrm{~N}$-enriched compared with the control plots, indicating an increase in the coupling of soil nitrogen availability and nitrogen loss pathways (e.g., [105]). The opposite patter was observed in the case of aerial misting over tree canopies, with a decrease in tree ring natural abundance $\delta^{15} \mathrm{~N}$ values in the nitrogen addition treatment compared to the control, suggesting a higher amount of nitrogen retention in the ecosystem instead [10]. The substantially higher level of canopy (including branches and bark) nitrogen retention in experiments where nitrogen is added to the canopy compared to nitrogen fertilizers to soils [85] shows that forest canopies can contribute significantly to nitrogen immobilization by trees and microbial communities within forest ecosystems and to reducing nitrogen loss pathways. These results also suggest that soil fertilization experiments can overestimate the role of nitrogen deposition in soil biogeochemical processes and overlook the role of tree canopies in retaining atmospheric nitrogen. However, the overall short duration of the manipulation experiments, the high nitrogen doses applied (compared to the ambient nitrogen deposition), and the difference in terms of forest structure (forest age and management) make it challenging to draw conclusions about long-term responses of canopy $v s$. soil nitrogen processes to simulated increase in nitrogen deposition.

Monitoring of the specific inorganic nitrogen chemical species (i.e., $\mathrm{NH}_{4}^{+}, \mathrm{NO}_{3}{ }^{-}$) in deposition and water collected underneath tree canopies as throughfall has shown that nitrogen deposition is substantially altered in its path through the canopy. Hence, comparisons of throughfall to bulk nitrogen deposition can demonstrate whether canopies are net sinks or sources for nitrogen. Increases in nitrogen fluxes in throughfall relative to bulk deposition have been observed particularly at high nitrogen deposition sites, which were attributed to leaching and washing of dry nitrogen deposition from the canopies by precipitation [48•, 66, 106-109]. In this case, tree canopies can still retain part of the atmospheric nitrogen, though this process can be masked by the high wash-off of dry nitrogen deposition $[110,111]$. On the other hand, lower nitrogen fluxes in throughfall than bulk deposition have also been reported (in temperate, boreal and tropical forests), and have been considered an indication of retention and consumption by tree canopies and associated epiphytes $[4$, $110,112-118]$ and of direct foliar uptake (e.g. [119, 120] ref. chapter 4). Differences were reported between conifer and deciduous forests in the percentage of canopy retention, with the former showing a higher interception of inorganic nitrogen from precipitation compared to the latter $[66,121]$. When focusing on canopy 'preference' in terms of nitrogen forms $\left(\mathrm{NH}_{4}{ }^{+}, \mathrm{NO}_{3}{ }^{-}\right.$and dissolved organic nitrogen), interesting differences were found. In general, a higher efficiency by tree canopies in retaining $\mathrm{NH}_{4}{ }^{+}$rather than $\mathrm{NO}_{3}{ }^{-}$was reported $[113,117 \bullet \bullet, 122 \bullet]$. However, some studies reported a stronger preferential retention of $\mathrm{NO}_{3}{ }^{-}$compared to $\mathrm{NH}_{4}{ }^{+}$, particularly under low nitrogen deposition (Fenn et al. [110] and reference therein, particularly Table 4).

The magnitude of canopy nitrogen retention has been associated with both forest nitrogen status and changes in atmospheric nitrogen deposition, with higher retention at low nitrogen availability and under low atmospheric nitrogen input (e.g., [123], [121] across EU, [117••] in Canada). This observation is important, as it suggests that - particularly for nitrogen deposition in the form of $\mathrm{NO}_{3}{ }^{-}$- canopy retention can significantly reduce the amount of atmospheric $\mathrm{NO}_{3}{ }^{-}$inputs to the soil (between 30 and $60 \%$ of the bulk deposition $[66,117 \cdot \bullet]$ ) and limit soil nitrogen loss pathways through leaching of $\mathrm{NO}_{3}{ }^{-}$and gas loss $[124,125]$. Different attributes related to forest structure and dynamics (e.g., diversity, phenology) seems also to be relevant in explaining differences in canopy nitrogen retention. A number of studies found that canopy 


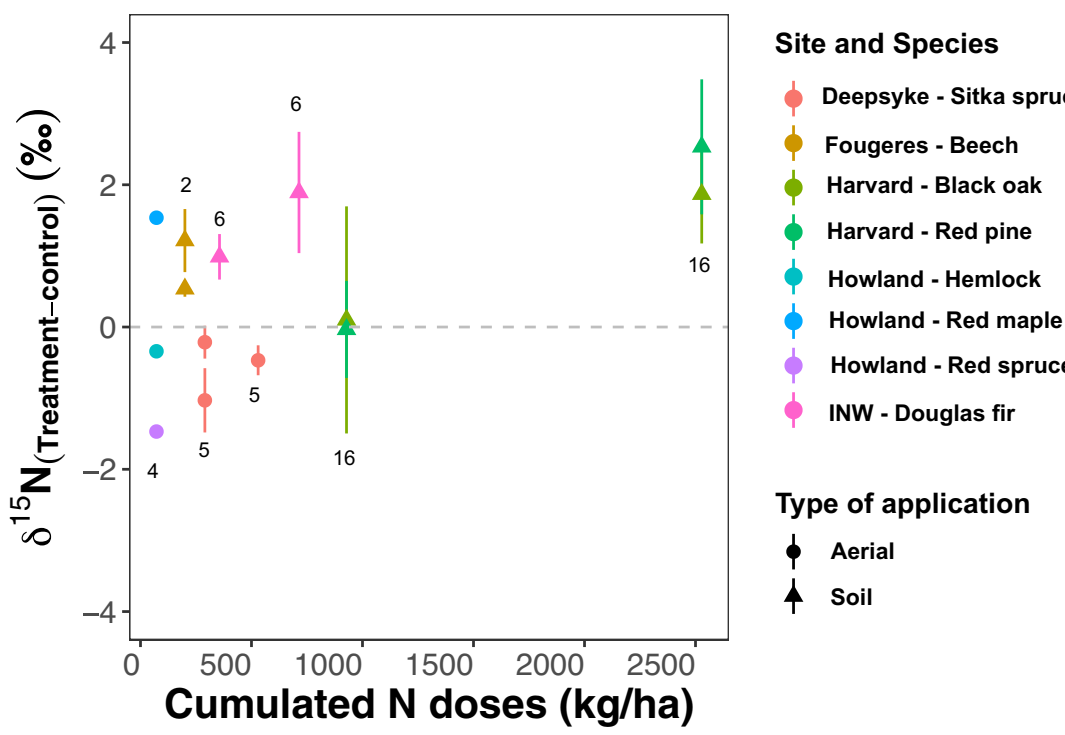

Fig. 3. Results of the meta-analysis presented in Guerrieri et al. (2011), showing natural abundance $\delta^{15} \mathrm{~N}$ values in tree rings (as difference between nitrogen fertilization and control) $v s$. cumulated doses of nitrogen $(\mathrm{N})$ applied over the duration of the experiments, which is indicated with numbers close to symbols. We updated the original figure in Guerrieri et al. (2011) by including also natural abundance $\delta^{15} \mathrm{~N}$ values measured for red maple, red spruce, and hemlock at Howland forest. Values are means with $95 \%$ confidence intervals and were measured during the years fertilization treatments were carried out. See Guerrieri et al. (2011) for more details on the meta analysis and supplementary information for a description of wood core collection and sample preparation at Howland forest. retention was typically higher during the growing season $[121,126,127]$ and that it was associated with forest diversity [121]. The latter is not surprising, particularly if we consider diversity not only in terms of different tree species but also their associated leaf and morphologies traits (which can affect ability of canopies to 'capture' atmospheric deposition) and life they host (ref. chapter 6).

Several studies have shown that when water from precipitation cascades through the canopy-via throughfall and stemflow-concentrations of dissolved organic matter (see review by Van Stan and Stubbins, 2018 [128]) and particulate organic matter (organic material ranging from $0.45 \mu \mathrm{m}$ and $500 \mu \mathrm{m}$; see review by Ward et al. [129]) can be significantly altered. With particular reference to nitrogen, monitoring dissolved and particulate organic nitrogen in bulk deposition and throughfall is not carried out routinely as in the case of dissolved inorganic nitrogen. Hence, it is hard to provide an overall picture about whether and in which direction organic nitrogen fluxes change when passing through tree canopies. Results in the literature vary from no changes $[70,130]$, to reduction (in tropical and boreal forests [115] and reference therein), and to an increase in dissolved [48•,70] and particulate [131] organic nitrogen fluxes in throughfall compared to bulk deposition. Causes for the significant increase in both dissolved and particulate organic nitrogen fluxes beneath tree canopies were related to leaching of canopy herbivore frass [132] or microbial biomass [131, 133••], pollen and bud burst [68•], or caterpillar [134] or fungi [135] infestations. These results suggest that canopy phenology can also control the inputs of organic nitrogen to the soil. Moreover, a more intensive monitoring of organic nitrogen fluxes in forests could help in detecting insect pests, which are becoming more frequent and severe with climate change [66, 136].

\section{Canopy Nitrogen Retention and Uptake: Why Distinguishing Between the Two Matters}

Canopy retention is often referred to as canopy uptake, though the two processes are quite different. Nitrogen that is retained in tree canopies - defined as 'the atmospheric $\mathrm{N}$ input to the canopy not reaching the forest soil' [126] could be adsorbed by leaf and branch/bark surfaces and/or associated microbes, but it does not necessarily mean that it is assimilated by plants via their foliage. In this chapter we specifically focus on the foliage nitrogen uptake pathway. Atmospheric nitrogen inputs represent an additional and readily available source of nitrogen that can be actively taken up by foliage and thus, be metabolized by plants $[4,119,137 \bullet \bullet, 138 \bullet, 139 \bullet \bullet, 140 \bullet \bullet, 141]$. This pathway can be particularly important for those ecosystems relying on fog for water and nutrients it carries, e.g., 
Sequoia sempervirens forests in California [137••] and Arthraerua leubnitziae in the Namibia desert [142•], as well as several tree species in wet tropical forest in the Republic of Panama [143••].

How does nitrogen uptake through canopy work and how can it be described? We remind readers of reviews by Sparks [119], Krupa [144] - with focus on $\mathrm{NH}_{3}$, and $\mathrm{Hu}$ et al. [145], which provide a comprehensive description of the foliar nitrogen uptake pathways and subsequent transport and metabolism (including associated genes and enzymes). Briefly, there are two pathways for $\mathrm{NH}_{3}$ to enter the leaves: through stomata and cuticles ( $[119,120]$ and reference therein). Stomatal uptake of $\mathrm{NH}_{3}$ depends on stomatal conductance and on the concentration gradient between atmosphere and substomatal cavities where $\mathrm{NH}_{3}$ is dissolved in the water film of the mesophyll cells to form $\mathrm{NH}_{4}{ }^{+}$. Atmospheric $\mathrm{NH}_{3}$ can also passively be deposited on leaf cuticles, where the presence of relative humidity can favor its solubility and conversion to $\mathrm{NH}_{4}{ }^{+}$, which can then be assimilated via cuticle or be reemitted. Oxidized forms of nitrogen (NO and $\mathrm{NO}_{2}$ ) enter foliage through stomata and dissolve in the leaf apoplast to primarily form nitrous acid $\left(\mathrm{HNO}_{2}\right)$ and nitric acid $\left(\mathrm{HNO}_{3}\right)$ that then dissociate to $\mathrm{NO}_{2}{ }^{-}$and $\mathrm{NO}_{3}{ }^{-}$ [119]. Though here we focus mostly on inorganic nitrogen, it is worth mentioning that foliar uptake of organic nitrogen has also been reported [146, 147].

Nair et al. [139••] conducted a mesocosm manipulation experiment with Sitka spruce saplings where, among other treatments, a solution containing isotopically enriched ${ }^{15} \mathrm{NH}_{4} \mathrm{NO}_{3}$ was sprayed on the soil and applied directly to twigs and needles through a brush presoaked with treatment solution. The input of nitrogen did not significantly add to the ambient nitrogen deposition experienced by the saplings (14.5 $\mathrm{kg} \mathrm{N} \mathrm{ha}^{-1} \mathrm{yr}^{-1}$, Nair 2021, personal communication), as only $54 \mathrm{~g}^{15} \mathrm{~N} \mathrm{ha}^{-1}$ year $^{-1}$ was added as tracer with the experiment. The study showed that $60 \%$ of ${ }^{15} \mathrm{~N}$ applied to the canopy was recovered in the aboveground components of trees (needles, stem and branches), while only $21 \%$ was recovered in aboveground biomass when ${ }^{15} \mathrm{~N}$ was applied to the soils. In another experiment carried out by Adriaenssens et al. [126], oak, birch, Scots pine, and beech saplings were exposed to different amounts of labeled ${ }^{15} \mathrm{NH}_{3}$. The authors found greater ${ }^{15} \mathrm{NH}_{3}$ uptake by birch, beech, and oak compared to pine, which was attributed to the lower nitrogen requirement by conifers in general, owing to high internal nitrogen recycling and longer retention time for needles [94••]. Moreover, results pointed to a reduction in ${ }^{15} \mathrm{NH}_{3}$ uptake at higher dose of nitrogen addition, which was attributed to possible attenuation by surface nitrifying bacteria (ref. chapter 6), increasing temporal storage of $\mathrm{NH}_{3}$ or reemission of $\mathrm{NH}_{3}$. In the manipulation experiments carried out at Howland Forest (ref. chapter 2) differences were observed between species in terms of nitrogen uptake in the subplots where labeled ${ }^{15} \mathrm{NH}_{4}{ }^{+}$ and ${ }^{15} \mathrm{NO}_{3}{ }^{-}$were sprayed over tree canopies. We already mentioned that contrary to the expectation, retention of the applied nitrogen was observed in branches and bark (particularly in the case of hemlock) rather than foliage. However, when looking at the difference between ${ }^{15} \mathrm{~N}$ values measured in foliage of trees treated with trace amounts of ${ }^{15} \mathrm{~N}_{-} \mathrm{NH}_{4}{ }^{+}$vs. ${ }^{15} \mathrm{~N}_{-} \mathrm{NO}_{3}{ }^{-}$, results suggested a preferential uptake of ${ }^{15} \mathrm{NO}_{3}{ }^{-}$ compared ${ }^{15} \mathrm{NH}_{4}{ }^{+}$in the case of hemlock, red spruce, and red maple, whereas the opposite was found for white cedar and white pine. In a manipulation experiment where hybrid poplar seedlings were exposed to $\mathrm{NO}_{2}$ fumigation, Siegwolf et al. [148] demonstrated the occurrence of foliar nitrogen uptake and assimilation, the latter confirmed also by an increase in nitrate reductase activity. Similar results were also reported in a subtropical forest in Shimentai National Nature Reserve (China, ref. Table 1), where 2 years of exposure to nitrogen misting over tree canopies resulted in an increase in leaf nitrogen and enzymes associated with leaf nitrogen metabolism (i.e., nitrate and nitrite reductase), though the latter result was not consistent across the three dominant species [6, $149 \bullet \bullet$.

Taken all together, results from these studies suggest that there are differences among species in the primary form of inorganic nitrogen taken up, and that nitrogen uptake could be controlled by the level of nitrogen deposition and by tree age. In this latter case it should be mentioned that only in the case of Howland and Shimentai forests adult trees were considered, whereas most studies focus on saplings [120, 126, 139••], often considering only a single pulse ${ }^{15} \mathrm{~N}$ tracer treatment [141]. The primary study of saplings is not surprising, given that manipulation experiments on small plants are easier to manage and responses to experimental treatment can be detected more quickly than under gradual increase in ambient nitrogen deposition with taller statured mature trees. However, as already highlighted, while manipulation experiments have greatly contributed to our understanding of important processes, such as foliar nitrogen uptake, their results can be biased by the short duration of the experiment and results may be difficult to generalize beyond sites or species considered.

Natural abundance $\delta^{15} \mathrm{~N}$ values in foliage and treerings has been used extensively as a tool to assess the assimilation by tree canopies of atmospheric nitrogen, particularly near emission sources such as motorways or industrial activity [150-153]. For example, Ammann et al. [150] observed an increase in $\delta^{15} \mathrm{~N}$ values measured in spruce needles and soil moving from trees near the highway (exposed to pollution) to those $1 \mathrm{~km}$ away. The authors attributed this variation in $\delta^{15} \mathrm{~N}$ values to the 
decreasing influence of $\mathrm{NO}_{2}$ input from traffic. The limitation of this approach, however, is that the isotopic signature of the atmospheric nitrogen sources is not always known, or it relies on point measurements (both in space and time), which makes difficult the interpretation of the long-term isotopic signals detected in plants (see [153, 154] for more details). In situ assessment of foliar nitrogen uptake, particularly in the oxidized form, has recently been assessed using dual $\left(\delta^{15} \mathrm{~N}\right.$ and $\delta^{18} \mathrm{O},[155]$ for a review) or triple $\left(\delta^{15} \mathrm{~N}, \delta^{18} \mathrm{O}\right.$ and $\left.\delta^{17} \mathrm{O}\right)$ isotope approaches. The simultaneous measurement of nitrogen and oxygen isotopes of plant tissue $\mathrm{NO}_{3}^{-}$has been successfully used to demonstrate foliar $\mathrm{NO}_{3}{ }^{-}$uptake in mosses [156] and herbaceous species [140•. $]$ and to assess plant $\mathrm{NO}_{3}{ }^{-}$sources and uptake for dominant plant species in Alaskan tundra ecosystems [157••]. Bourgeois et al. [140••] demonstrated not only the foliar uptake of $\mathrm{NO}_{3}{ }^{-}$in subalpine grassland species, but also seasonal shifts in $\mathrm{NO}_{3}{ }^{-}$uptake; the plants relied on roots for nitrogen uptake in spring after snowmelt, and on leaves in summer, likely due to higher competition with soil microbes. More studies are needed to confirm whether these seasonal dynamics also occurs with trees.

The canopy nitrogen uptake pathway is included in mechanistic models, such as the canopy budget model [52], which is used to estimate dry deposition. This model is based on balancing ion exchange between canopies and the solutions passing through them, so that the total deposition beneath tree canopies (including throughfall, TF and stemflow, $\mathrm{SF}$ ) is given by: $T F+S F=T D+C E=P D+$ $D D+C E$, where TD and CE are total atmospheric deposition (e.g., open field wet, PD + dry, DD, depositions) and canopy exchange, respectively. The canopy exchange (CE) in the interface between wet atmospheric deposition and tree canopy surface is the main process governing the uptake and release of the major ions. For a given ion, a positive $\mathrm{CE}$ value indicates that tree canopies contribute to $\mathrm{TF}+\mathrm{SF}$ flux via leaching, while a negative $\mathrm{CE}$ value is associated with canopy uptake. For inorganic nitrogen, the assumption is that uptake of $\mathrm{NH}_{4}{ }^{+}$and/or $\mathrm{H}^{+}$by tree canopies goes along with the release of base cations, such as $\mathrm{K}^{+}, \mathrm{Ca}^{2+}$, and $\mathrm{Mg}^{2+}$. For $\mathrm{NO}_{3}{ }^{-}$it is often assumed that neither canopy leaching nor uptake occurs ([52] and references therein), though recent developments of the canopy budget model include canopy $\mathrm{NO}_{3}{ }^{-}$uptake as a proportion of $\mathrm{NH}_{4}{ }^{+}$uptake [158]. It should be pointed out, however, that the negative $\mathrm{CE}$ for $\mathrm{NH}_{4}{ }^{+}$or $\mathrm{NO}_{3}{ }^{-}$might indicate retention rather than uptake, as we do not know whether nitrogen is actually assimilated by foliage. Moreover, the model does not account for possible nitrogen transformations occurring in tree canopies by epiphytes and/or microbes associated with foliage (as we will see in the next chapter). Nevertheless, the approach certainly contributes to improving quantification of total nitrogen deposition reaching forest ecosystems, when direct measurements of dry deposition are not available $[48 \bullet$.

\section{Biological Transformation in Tree Canopies: Hints From Stable Isotopes of Nitrogen and Oxygen}

Tree canopies and epiphytes they host contribute significantly to altering the nitrogen fluxes and type of nitrogen compounds reaching the soil. Nitrogen retention and uptake are the main mechanisms proposed to explain differences in nitrogen fluxes between bulk deposition and throughfall (e.g., canopy budget model). Yet, looking at differences between fluxes together with changes in isotopic composition of different nitrogen forms that enters canopies from the atmosphere and those that pass to the forest floor provide evidence of within-canopy biological transformations. The measure of natural abundance stable isotopes of nitrogen $\left({ }^{15} \mathrm{~N} /{ }^{14} \mathrm{~N}\right)$ and oxygen $\left({ }^{17} \mathrm{O} /{ }^{16} \mathrm{O}\right.$, $\left.{ }^{18} \mathrm{O} /{ }^{16} \mathrm{O}\right)$ in forest water has proven to be a powerful tool to characterize the sources of atmospheric nitrogen ( [159-161], and [162••] for a review) and to trace its transformations when interacting with tree canopies [111, $163-166 \bullet \cdot$. We have a comprehensive theoretical understanding of isotopic fractionation during soil biogeochemical processes and nitrogen transfer to plant [167]. Yet, discriminating between nitrogen compounds derived from atmospheric transformations occurring within tree canopies and how they affect the isotopic signatures of $\mathrm{N}$ compounds produced (e.g., those taken up and/or leached) are less understood.

For instance, $\mathrm{NH}_{4}{ }^{+}$and $\mathrm{NO}_{3}{ }^{-}$derived from dry nitrogen deposition is in general more enriched in ${ }^{15} \mathrm{~N}$ (that is more positive $\delta^{15} \mathrm{~N}$ values) compared to those measured in bulk precipitation [167]. However, a decrease in $\delta^{15} \mathrm{~N}^{\text {in }} \mathrm{NO}_{3}{ }^{-}$from bulk deposition to throughfall was reported in a spruce forest in Germany [168], a montane rainforest in Ecuador [169], and Scots pine in the UK [165••], indicating isotopic fractionation during nitrification of $\mathrm{NH}_{4}{ }^{+}$to $\mathrm{NO}_{3}{ }^{-}$in the canopy foliage. Indeed, nitrification of $\mathrm{NH}_{4}{ }^{+}$leads to the production of ${ }^{15} \mathrm{~N}$ depleted $\mathrm{NO}_{3}{ }^{-}$and leaves behind more ${ }^{15} \mathrm{~N}$ enriched $\mathrm{NH}_{4}{ }^{+}$ $[167,170]$.

More direct evidence of nitrification occurring in tree canopies could derive from the dual isotope approach, which includes measurement of both $\delta^{15} \mathrm{~N}$ and $\delta^{18} \mathrm{O}$ in $\mathrm{NO}_{3}{ }^{-}$. This approach has been extensively applied to 
investigate soil biological transformations and to assess the nitrogen saturation status of forested catchments by looking at the changes in $\delta^{18} \mathrm{O}$ of $\mathrm{NO}_{3}{ }^{-}$in bulk deposition and streamwater $[160,171-173 \bullet \bullet]$. A large difference between the isotopic signature of the atmosphericallyderived $\mathrm{NO}_{3}^{-}$(20 to $80 \%$ - ref. Appendix 1) and the terrestrial $\mathrm{NO}_{3}^{-}$(particularly biological transformation, such as nitrification) $(-10$ to $+10 \%$, ref. [160] for a review) can help distinguish between the two sources. For instance, based on this approach, a number of studies in the northeastern US $[111,171]$ found that $\mathrm{NO}_{3}{ }^{-}$in streamwater comes primarily from nitrification within the catchment rather than directly from atmospheric deposition. Yet, only a limited number of studies used the dual isotope approach to assess the occurrence of canopy nitrification $\left([111,165 \bullet, 174 \bullet \bullet]\right.$. Increases in $\mathrm{NO}_{3}{ }^{-}$concentrations and reduction in both $\delta^{18} \mathrm{O}$ and $\delta^{15} \mathrm{~N}^{\text {in }} \mathrm{NO}_{3}{ }^{-}$in filtered throughfall water collected underneath Cryptomeria japonica was attributed to nitrification in tree canopies [174.•]. Similar results were reported by Guerrieri et al. [165*0] in a beech and Scots pine forests exposed to $>10 \mathrm{~kg} \mathrm{~N} \mathrm{ha}^{-1} \mathrm{yr}^{-1}$ in the UK, which was further supported by the isotopic mass balance approach combining the $\delta^{18} \mathrm{O}$ of the two different sourcesatmosphere (wet atmospheric $\mathrm{NO}_{3}^{-}$) and nitrification $\left(\mathrm{NO}_{3}{ }^{-}\right.$washed off tree canopies and collected in throughfall water). There are, however, limitations of the dual isotope approach (at least when applied to $\mathrm{NO}_{3}{ }^{-}$in the soil). These include $i$ ) the fact that there is overlap in isotopic composition among nitrate sources (e.g., nitrification and atmospheric deposition) and ii) that the isotopic signature of $\mathrm{NO}_{3}{ }^{-}$is significantly altered by isotopic fractionation during denitrification - a process that leads to a high enrichment in ${ }^{15} \mathrm{~N}-\mathrm{NO}_{3}{ }^{-}$left behind during the biological process and then available for plant uptake ( [160] and references therein, [167], and the earlier study by Mariotti [175]). Moreover, there are uncertainties in the estimates of atmospheric vs. biological $\mathrm{NO}_{3}{ }^{-}$fractions as obtained by the isotopic mass balance approach, mostly associated with the $\delta^{18} \mathrm{O}$ produced during nitrification (we refer readers to the discussion in Riha et al. [176] and Guerrieri et al. [165••] for more details).

A more robust approach to partitioning sources of $\mathrm{NO}_{3}{ }^{-}$ is based on measurements of both $\delta^{17} \mathrm{O}$ and $\delta^{18} \mathrm{O}$ in $\mathrm{NO}_{3}{ }^{-}$, which allows researchers to distinguish between atmospheric and microbial (through nitrification) sources of $\mathrm{NO}_{3}{ }^{-}$. The approach was proposed by Michalski et al. $[177,178 \cdot \bullet]$ and since then has been used in a number of studies assessing the source of $\mathrm{NO}_{3}{ }^{-}$in soil solution in forests [179] or streamwater at the catchment level [176, $180,181 \bullet \cdot$. Briefly, mass-dependent isotope fractionation leads to a consistent relationship between $\delta^{17} \mathrm{O}$ and $\delta^{18} \mathrm{O}$, i.e., : $\delta^{17} O \approx 0.52 \times \delta^{18} O$, which follows the so-called mass dependent fractionation line. However, mass independent fractionation occurs during the formation of ozone and leads to excess in ${ }^{17} \mathrm{O}$, which is then reflected in the $\delta^{17} \mathrm{O}$ of the atmospheric $\mathrm{NO}_{3}{ }^{-}$. This excess ${ }^{17} \mathrm{O}$ is quantified by $\Delta^{17} O=\delta^{17} O-0.52 \times \delta^{18} O$ [177]. This means that in the case of $\mathrm{O}_{3}$-derived $\mathrm{NO}_{3}{ }^{-}, \delta^{17} \mathrm{O}$ values tends to deviate from the mass dependent fractionation line, resulting in $\Delta^{17} \mathrm{O}>$ 0 , while mass-dependent nitrification produces $\mathrm{NO}_{3}{ }^{-}$with $\Delta{ }^{17} \mathrm{O}=0$ [178]. Combining this information with a mass balance approach makes it possible to calculate the fractions of $\mathrm{NO}_{3}{ }^{-}$coming from the two different sources, i.e., atmospheric $v s$. terrestrial sources (particularly nitrification of either $\mathrm{NH}_{4}{ }^{+}$from wet deposition, soil $\mathrm{NH}_{4}{ }^{+}$pool, and/or fertilizer applications [182, 183].

While the triple isotope approach $\left(\delta^{15} \mathrm{~N}, \delta{ }^{17} \mathrm{O}\right.$ and $\delta^{18} \mathrm{O}$ in $\mathrm{NO}_{3}{ }^{-}$) has been mostly applied to assess the contribution of atmospheric vs. biological sources for $\mathrm{NO}_{3}{ }^{-}$in streamwater to elucidate nitrogen loss pathways associated with leaching $[176,183]$, very few studies have applied it to investigate the occurrence of canopy nitrogen transformations. Guerrieri et al. [165••] measured multiple isotopes in bulk precipitation and throughfall water (i.e., $\delta^{15} \mathrm{~N}$ in $\mathrm{NH}_{4}{ }^{+}$and $\delta^{15} \mathrm{~N}, \delta^{18} \mathrm{O}$ and $\Delta^{17} \mathrm{O}$ in $\mathrm{NO}_{3}{ }^{-}$) collected at two Scots pine and two beech forests at contrasting levels of nitrogen deposition. Using this approach, the authors found that forests under high nitrogen deposition have a significant fraction of the nitrate in throughfall derived from nitrification in tree canopies (higher for beech $(59 \%)$ compared to Scots pine (17\%)), and less from atmospheric nitrogen deposition. Nitrification in tree canopies was also detected in a Mediterranean holm-oak forest, though these exposed to lower nitrogen deposition compared to the sites in the UK [166••]. If stable isotopes (particularly $\Delta^{17} \mathrm{O}$ in $\mathrm{NO}_{3}^{-}$) provide indications on biological transformations occurring in tree canopies, can we identify microbes responsible for them?

\section{Phyllosphere Epiphytes and Their Role in Processing Atmospheric Nitrogen Within Canopies}

Forest canopies represent an important habitat (i.e., phyllosphere) for epiphytes and endophytes, which include lichens ( [184-186] for a review] and microbes, i.e., archaea, bacteria, and fungi [187-190] for a review - Fig. 4].

The total extent of global phyllosphere habitat is thought to represent $6.4 \times 10^{8} \mathrm{~km}^{2}$, which could harbor $10^{26}$ bacterial cells [190-192]. A strong association 

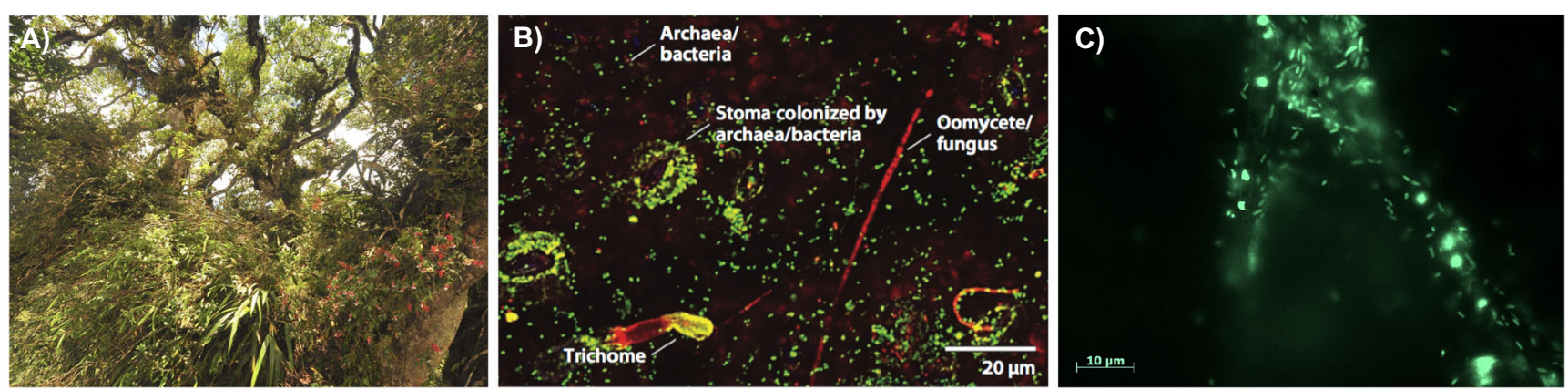

Fig. 4. Example of life diversity in tree canopies. View of the diversity of epiphytes within the canopy of Ficus tuerckheimii as reported in Gotsh et al. 2015 (panel A). Phyllosphere microbes in the lower surface of a Quercus robur and a Fagus sylvatica leaves (panel B and C,

between leaf traits (such leaf mass per area, leaf thickness, leaf area and leaf nutrient, and pigments associated to photosynthesis) and bacterial [189••] and fungi [193••] phyllosphere communities was reported. Despite epiphytic microbes representing an important component of tree canopies $[194,195 \bullet \cdot]$, attention has been mostly directed to their role as pathogens, while we still do not know whether and how they affect nutrient cycling [187, 190]. Moreover, earlier studies were mostly based on the use of laboratory cultures, making difficult to actually characterize which microbial communities live in forest canopies. The advent of high throughput sequencing and recent omic techniques offer a great opportunity to take a snapshot of the microbes living in the phyllosphere to characterize community composition and to explore the functional role of taxa within these communities.

Several studies have provided information on species composition of microbial communities in the phyllosphere (cf., $[188,189 \bullet \cdot, 196])$. Leaves often share a similar bacterial composition regardless of the position within the canopy $[166 \bullet \bullet, 196]$, while leaf age and phenology (i.e., leaf development) and climate affect composition and diversity of the bacterial communities they host, though most results refer to the canopy of herbaceous species. More diverse bacterial communities in younger compared with older leaves were observed ( $[197,198]$ on crop plants; [199••] in urban forests), likely associated with the decrease in nutrient availability from the host plant. Experimental increase in temperature and atmospheric $\mathrm{CO}_{2}$ enhanced richness and diversity of bacteria in phyllosphere of Galium alba [200] and 'Koshihikari' rice plants [201]. Similar results were also observed in the case of phyllosphere of Quercus ilex trees subjected to drought [202]. respectively). Image in the panel $\mathbf{B}$ was taken from Vacher et al. (2016). Image in the panel $\mathbf{C}$ was obtained by epifluorescence microscopy on DAPI-stained cells, showing bacteria (green dots) on leaf surface, along the main veins (copyright Rossella Guerrieri)
Compared to microbial communities living in the soil, those in the phyllosphere experience more rapid (from diurnal to seasonal) changes in environmental conditions, including ultraviolet radiation, relative humidity, temperature, carbon, and nutrients availability [195••, 203•]. While effects of biotic and abiotic stress on the microbial communities have been discussed [187, 194], we are not aware of any investigations conducted to determine whether and how changes in nitrogen deposition affect abundance of microbial taxa associated with nitrogen transformations.

A proteomic approach allows researchers to detect enzymatic functions of bacteria in the phyllosphere, such as enzymes able to convert methanol to obtain carbon and assimilate $\mathrm{NH}_{4}{ }^{+}$via glutamine synthetase $[188,204 \bullet \bullet]$. Biological nitrogen fixation (the process that converts atmospheric $\mathrm{N}_{2}$ to reactive nitrogen in the form of $\mathrm{NH}_{4}{ }^{+}$) is mostly attributed to symbiotic nitrogen fixers found in root nodules. Yet, there is mounting evidence of the occurrence of nitrogen fixation in tree canopies of different forest ecosystems, mediated by free-living archaea and bacteria nitrogen fixers $[205,206]$ for a review] that are associated with foliage or epiphytes (e.g., [207-210••] in tropical forests, [211] in a Mediterranean forest, [212••, 213] in a temperate forests). Indeed, nitrogen fixation by microbes associated with epiphytes has been shown to be particularly relevant for old growth forests, characterized by the significant abundance of epiphytes in their canopy, such as in coastal temperate rain forests in British Columbia [214]. A recent study in the Niwot Ridge in the US [212••] showed $\mathrm{N}_{2}$-fixing acetic acid bacteria living as endophytes on limber pine needles. Moreover - and most importantly - the authors demonstrated that the fixed nitrogen diffused inside the needles and entered plant metabolism, as indicated by the increase in nitrogenase 
activity. Recent studies showed that almost $50 \%$ of the nitrogen derived from nitrogen fixation was carried out above- ground on tree trunks and within tree canopies of tropical forests in French Guiana [209••] and in Brazil [210••]. Interestingly, canopy nitrogen fixation seems to increase with foliar phosphorous $[208 \bullet \bullet, 210 \bullet \cdot]$ and is not limited by drought conditions [210••, 211].

Nitrogen fixation, however, may not be the only biological transformation occurring in tree canopies. A number of studies have provided evidence of nitrifying microbes harbored in the phyllosphere. Indeed, nitrifying bacteria were found within the apoplast of needles in a spruce forest in Germany subjected to high nitrogen deposition $[215,216]$, or archeal amoAOA genes related to nitrification were found on foliar in a Cryptomeria japonica forest in Japan [174••]. Both archaeal and bacterial amoA genes were found on the phyllopshere of Quercus ilex in a Mediterranean forest, whose activity in processing atmospheric nitrogen deposition through nitrification within tree canopies was assessed by using $\Delta^{17} \mathrm{O}$ in bulk deposition and throughfall, as described in the previous chapter [166••]. The presence of $\mathrm{NO}_{2}-\mathrm{N}$ and organic $\mathrm{N}$-using fungi were observed on needles collected at top and intermediate branches of black spruce trees in Canada [116], which contributed also to significantly changing nitrogen fluxes at various canopy heights.

This information provides important evidence, yet site-specific, for the presence and activity of nitrogen-related microbes in the phyllosphere, but additional studies-either along climate and nitrogen deposition gradients or for different forest ecosystem types - are needed to better quantify those processes at larger scales. Moreover, extending the characterization of microbial communities to bulk deposition, throughfall and stemflow water other than the phyllosphere, would provide a deeper understanding of ecosystem nitrogen dynamics associated with microbial dispersion (e.g., in relation to the origin of air masses, see [217•]), interception by tree canopies and their release during a rainy event [218••], thus, contributing to enriching the microbial communities in the soil [133••]. Intrusion of dust from the Sahara Desert (i.e. air masses from northern Africa) has been shown to enrich the air mass with nutrients and allochthonous microbial components [208••], and changes both composition and diversity of bacterial communities [166••, 217•, 219]. Bittar et al. [133••] estimated a flux of $1.5 \times 10^{16}$ microbial cells ha ${ }^{-1}$ year $^{-1}$ to the soil from throughfall in a subtropical oak-cedar forest in Southeastern USA, which corresponded to a contribution of organic carbon from the phyllosphere to the soil of $0.6-2.3 \mathrm{~kg}$ $\mathrm{ha}^{-1}$ year $^{-1}$. In a study carried out on a holm oak forest in Spain precipitation water and the phyllosphere shared some of the same bacterial taxa, which were not found in throughfall water, suggesting that tree canopies may act as a filter not only for atmospheric chemical compounds, but also for microbes carried by precipitation $[166 \bullet \bullet$.

The canopy organic mat, which includes tree canopies and associated epiphytes, invertebrates, and microbes, has been acknowledged as 'nutrient capital' [220], particularly in tropical moist forest ecosystems. Indeed, dead canopy organic matter undergoes decomposition processes, which lead to the formation of the so-called 'crown humus' [221], which is commonly referred to as 'arboreal soil' [222] or 'canopy soil' [220]. Canopy soil has been less studied compared to soil in the forest floor, given the challenges associated with the sampling, though several studies have pointed to its ecological relevance $[220,222,223 \bullet \cdot]$. Indeed, canopy soil is a repository of nutrients (including nitrogen) epiphytes and other living organisms rely on, which either derives from decomposition and mineralization of the dead organic matter or retention of atmospheric deposition [222, 224, 225]. Mineralization and nitrification in canopy soils of a tropical montane forest in Ecuador were limited by nitrogen availability, suggesting that increases in nitrogen deposition can enhance nutrient cycling occurring in tree canopies [220]. Last, but not least, soils in tree canopies and in the forest floor are interconnected thanks to leaching of nutrients through throughfall and stemflow [223••, 226], but also via invertebrate species [227-229]. As suggested by Van Stan et al. [230••], throughfall can be seen like a 'hydrological highway' connecting the atmosphere to the soil, thus, allowing inorganic and organic nitrogen and biological materials (derived from plants, epiphytes and/or microbes) to be transferred to the soil.

\section{Conclusions}

Back in 1971, Hill [231] stated "It has often been observed that we know much more about the sources, movement, and effects of air pollutants than we do about their fate". Since then, significant progress have been made from different research communities to elucidate the fate of air pollutants (including reactive nitrogen) and the crucial role that tree canopies play in altering nitrogen inputs from the atmosphere by retaining, assimilating, and transforming nitrogen deposition before it reaches the soil. The complexity of living organisms and the role they play in nutrient cycling has been well studied in forest soils [232]. We have just started to unveil the high diversity in microbial life in tree canopies and we are still far from understanding their roles in nitrogen cycling. How to move forward? The following represents research areas we suggest should be prioritized for next steps in this field, encouraging multidisciplinary approaches across different research communities interested in - but not limited to - nitrogen cycling in forest ecosystems. 
- We suggest that researchers develop improved approaches to obtain more robust estimates of total nitrogen deposition. Satellite observations and modeling approaches play a crucial role in increasing the spatial coverage of atmospheric reactive nitrogen concentrations and deposition data, but there are several critical points that need to be solved to improve estimates of both wet and dry deposition, which are both needed in order to estimate total deposition (ref. [65•, 233] for an overview). For instance, satellite-based estimates of $\mathrm{NH}_{3}$ deposition do not account for bi-directional fluxes during the interaction between the biosphere and atmosphere [234, 235]. Ground-based observations cannot be replaced entirely by remote sensing data since canopy nitrogen processes (and their contribution to the ecosystem nitrogen cycling) have to be quantified. Moreover, weighting of the land-use classes within grid cell used for processing satellite data may not be representative of the vegetation type in the site of interest, thus, leading to uncertainties in the deposition estimates $[56,233]$.

- It is important to increase the monitoring of atmospheric deposition in places that are under-represented in our understanding of atmospheric nitrogen deposition, such as in tropical regions or urban environments (the latter being hotspots of atmospheric deposition [36•, 74•]). We recommend greater use of ion exchange resin collectors [37, 38]. Establishing an intensive monitoring network in the tropics (and other under-represented region in the world) is paramount to achieving a better understanding of the ecological consequences of increasing nitrogen deposition on nitrogen cycling and trade-offs between canopy and soil processes, as well as forest carbon and water fluxes. Moreover, including stable isotope analyses, particularly the use of $\Delta^{17} \mathrm{O}$, in addition to quantification of nitrogen fluxes would greatly further our understanding of the impacts of atmospheric $\mathrm{NO}_{3}{ }^{-}$deposition on forest ecosystems and elucidating processes occurring during atmosphericforest canopy interactions.

- Though more challenging from logistic and economic standpoints, we need to maintain current and establish more canopy nitrogen manipulation experiments in different forest ecosystems, particularly those where rates of nitrogen deposition are predicted to increase over the next several decades. Next-generation manipulation experiments should also simulate the increase in dry nitrogen deposition, particularly ammonia [236] or a reduction of nitrate deposition (i.e., particularly wet deposition), and explore the interactions between changes in nitrogen deposition and extreme climate events. Moreover, in addition to the response of trees, new experiments should include measurements of microbes in both the phyllosphere and rhizosphere.
- We recommend greater quantification of the relevance of canopy nitrogen uptake and canopy production-via microbial nitrification and fixation or biological activity by insects (e.g., insect frass) and trees themselves (i.e., e.g., pollen production, plant debris) - to better understand whole ecosystem nitrogen cycling. Recent studies highlighted the substantial contribution of asymbiotic nitrogen fixation in the phyllosphere [210••]. However, it remains to be estimated how much of this process contributes to ecosystem-scale biological nitrogen fixation, particularly in relation to increases in nitrogen inputs from anthropogenic activities, which could affect also tropical regions - where most of the studies on nitrogen fixation have been conducted so far [237]. We are far from understanding dynamics of nitrification in tree canopies - its magnitude, how it is affected by climate and nitrogen deposition and in which proportion it contributes to increase $\mathrm{NO}_{3}{ }^{-}$concentrations in soil solution. Providing robust estimates of canopy nitrogen uptake (and assimilation) and accounting for biological transformations within tree canopies can greatly improve estimates of total nitrogen deposition (e.g., through canopy budget model) and also improve the contribution of nitrogen input (from biological fixation and anthropogenic nitrogen deposition) to forest carbon sequestration, as represented in process-based [238] and terrestrial-biosphere models [239].

- We need to enhance our understanding of tree canopy-soil interactions. Tree canopies and soil are more interconnected than we think, as what is happening in the canopy (in terms of atmospheric nitrogen retention and uptake by foliage, branches and life they harbor and biological transformations by microbes in the phyllosphere) has the potential to affect soil microbial communities (via throughfall water 'highway' [230••]), and hence biogeochemical processes throughout a forest ecosystem [240••]. The advent of next-generation sequencing technologies [241] has increased our ability to study microbial communities (metagenomic) and their function (metatranscriptomic and metaproteomic) directly in the environment they live. A great example is the study by Delgado-Baquerizo et al. [232] mapping soil bacterial communities for different vegetation systems worldwide using metagenomic analyses. This recent development of new techniques is an exciting opportunity for forest ecologists to go beyond the greening of the canopies and their role in regulating carbon and water exchanges with the atmosphere and to assess their contribution to nutrient cycling. This means taking a more holistic approach, which explores i) the important contribution of forest water as input not only for nutrients, but also microbes; ii) the metabolic and functional role of microbes in the phyllosphere and their associations with their host trees. Mapping phyllosphere and forest water microbial communities, moreover, could represent an important 
addition to the very challenging earth microbiome project, the global collaborative effort to characterize microbial life on Earth (https://www.earthmicrobiome.org/publications/).

Supplementary Information The online version contains supplementary material available at https://doi.org/10.1007/s40725-021-00141-y.

Acknowledgements We thank the Editor for encouraging us to write this review and the two anonymous reviewers for their constructive and supportive comments on earlier version of this manuscript. R.G. acknowledges David Hollinger for his assistance in sampling wood cores at the manipulation experiment at Howland forest (USA) and research funding within the Newton International Fellowship from the Newton International Fellowship (Grant no. NF082365, 2009-2011) funded by the Royal Society, the British Academy, and the Royal Academy of Engineering, which supported stable isotope analyzes. R.G. thank Gerardo Guerrieri for the illustration in Fig. 1, and Joan Cáliz and Mateu Menéndez-Serra (Center for Advanced Studies of Blanes, Spain) for the support with microscope observations and image in the Fig. 4C.

Funding Open access funding provided by Alma Mater Studiorum Università di Bologna within the CRUI-CARE Agreement.

\section{Declarations}

Conflict of Interest Rossella Guerrieri, Pamela Templer, and Federico Magnani declare that they have no conflict of interest.

Human and Animal Rights This article does not contain any studies with human or animal subjects performed by any of the authors.

\section{Appendix}

\section{Stable isotope terminology and measurements}

Natural abundance of stable isotope composition of plant or nitrogen compounds in water samples are expressed as a ratio relative to an internationally accepted reference standard (Table 2), which is refered to as stable isotope composition (delta notation, $\delta$ ):

$\delta^{x x} E=1000 \times\left(\frac{R_{\text {sample }}}{R_{\text {standard }}}-1\right)$

where $E$ is the element of interest and "xx" is the mass of the rarest (and heavier) isotope in the abundance ratio (e.g., ${ }^{15} \mathrm{~N},{ }^{18} \mathrm{O}$ or ${ }^{17} \mathrm{O}$ in this review) and $\mathrm{R}$ is the abundance ratio of the two isotopes of interest (e.g., ${ }^{15} \mathrm{~N} /{ }^{14} \mathrm{~N},{ }^{18} \mathrm{O} /{ }^{16} \mathrm{O}$ or ${ }^{17} \mathrm{O} /{ }^{16} \mathrm{O}$ for this review). The isotope composition of a given sample is indicated as $\delta^{15} \mathrm{~N}, \delta^{18} \mathrm{O}$ or $\delta^{17} \mathrm{O}$, and it can be obtained through mass spectrometer analyses - albeit sample preparation, which can differ depending on the sample type and the isotopic composition of interest. Note that the absolute $\mathrm{R}$ of the sample is very small (a few part per thousand). For this reason the isotopic composition is expressed in 'per mill' notation $(\% o$ - which, hence, is not a unit.

Open Access This article is licensed under a Creative Commons Attribution 4.0 International License, which permits use, sharing, adaptation, distribution and reproduction in any medium or format, as long as you give appropriate credit to the original author(s) and the source, provide a link to the Creative Commons licence, and indicate if changes were made. The images or other third party material in this article are included in the article's Creative Commons licence, unless indicated otherwise in a credit line to the material. If material is not included in the article's Creative Commons licence and your intended use is not permitted by statutory regulation or exceeds the permitted use, you will need to obtain permission directly from the copyright holder. To view a copy of this licence, visit http://creativecommons.org/licenses/by/4.0/.
Table 2 The element, their isotopes and percent abundance, isotope abundance measured and international standard considered. We also mention the sample types where used in the examples provided in chapters 4 and 5 of the review and references the readers can refer to for more details regarding methdological aspects (sample preparation and measurements, which is particular relevant in the case of water samples).

\begin{tabular}{|c|c|c|c|c|c|c|}
\hline Element & Isotope & $\begin{array}{l}\text { Percent } \\
\text { abundance }\end{array}$ & $\begin{array}{l}\text { Isotope } \\
\text { abundance }\end{array}$ & Standard & Sample & Reference \\
\hline $\mathrm{N}$ & $\begin{array}{l}{ }^{14} \mathrm{~N} \\
{ }^{15} \mathrm{~N}\end{array}$ & $\begin{array}{l}99.63 \\
0.3663\end{array}$ & ${ }^{15} \mathrm{~N} /{ }^{14} \mathrm{~N}$ & $\mathrm{~N}_{2 \text {-atm }}$ & $\begin{array}{l}\text { Foliar and tree ring samples, } \\
\text { atmospheric nitrogen } \\
\text { deposition }\end{array}$ & $\begin{array}{l}{[105} \\
160 \\
162 \bullet \bullet \\
164]\end{array}$ \\
\hline $\mathrm{O}$ & ${ }^{16} \mathrm{O}$ & $\begin{array}{l}99.759 \\
0.037 \\
0.204\end{array}$ & $\begin{array}{l}{ }^{18} \mathrm{O} /{ }^{16} \mathrm{O} \\
{ }^{17} \mathrm{O} / 1^{6} \mathrm{O}\end{array}$ & V-SMOW & $\begin{array}{l}\text { Foliar, nitrogen compounds in } \\
\text { bulk, throughfall deposition } \\
\text { and streamwater }\end{array}$ & $\begin{array}{c}{[160} \\
162 \bullet \bullet \\
177 \\
178 \bullet \bullet]\end{array}$ \\
\hline
\end{tabular}

Note. $\mathrm{N}_{2 \text {-atm }}$ and V-SMOW indicates atmospheric $\mathrm{N}_{2}$ and Vienna-SMOW (the latter available from the IAEA. Table was modified from Dawson T.E., Mambelli S., Plamboeck A.H., Templer P.H., Tu K.P. Stable isotopes in plant ecology. Annu. Rev. Ecol. Syst. 2002; 33:507-59. 


\section{References}

Papers of particular interest, published recently, have been highlighted as:

- Of importance

- Of major importance

1. Friedlingstein $\mathrm{P}, \mathrm{O}$ 'Sullivan M, Jones MW, Andrew RM, Hauck J, Olsen A, et al. Global Carbon Budget 2020. Earth Syst Sci Data. 2020;12:3269-340.

2. Schlesinger $\mathrm{WH}$, Jasechko S. Transpiration in the global water cycle. Agric For Meteorol. 2014;189-190:115-7.

3. Bright RM, Zhao K, Jackson RB, Cherubini F. Quantifying surface albedo and other direct biogeophysical climate forcings of forestry activities. Glob Chang Biol. 2015;21:3246-66.

4. Sievering H, Tomasewski T, Torizzo J. Canopy uptake of atmospheric $\mathrm{N}$ deposition at a conifer forest. Part I. Canopy N budget, photosynthetic efficiency and net ecosystem exchange. Tellus B. 2007;59:483-92.

5. Wortman E, Tomaszewski T, Waldner P, Schleppi P, Thimonier A, Eugster W, et al. Atmospheric nitrogen deposition and canopy retention influences on photosynthetic performance at two high nitrogen deposition Swiss forests. Tellus B. 2012;64:17216.

6.• Liu N, Wang J, Guo Q, Wu S, Rao X, Cai X, et al. Alterations in leaf nitrogen metabolism indicated the structural changes of subtropical forest by canopy addition of nitrogen. Ecotoxicol Environ Saf. 2018;160:134-43 Important results from a canopy nitrogen manipulation experiment in a subtropical forest in China reporting on in situ leaf nitrogen uptake and assimilation and its effects on photosynthesis.

7. Fleischer K, et al. The contribution of nitrogen deposition to the photosynthetic capacity of forests. Glob Biogeochem Cycles. 2013;27:1-13.

8. Gentilesca T, Rita A, Brunetti M, Giammarchi F, Leonardi S, Magnani F, et al. Nitrogen deposition outweighs climatic variability in driving annual growth rate of canopy beech trees: evidence from long-term growth reconstruction across a geographic gradient. Glob Chang Biol. 2018;24:2898-912.

9. Etzold S, et al. Nitrogen deposition is the most important environmental driver of growth of pure, even-aged and managed European forests. For Ecol Manag. 2020;458:117762 (13 pp).

10. Guerrieri R, Mencuccini M, Sheppard LJ, Saurer M, Perks MP, Levy $\mathrm{P}$, et al. The legacy of enhanced $\mathrm{N}$ and $\mathrm{S}$ deposition as revealed by the combined analysis of $\delta^{13} \mathrm{C}, \delta^{18} \mathrm{O}$ and $\delta^{15} \mathrm{~N}$ in tree rings. Glob Chang Biol. 2011;17:1946-62.

11. Peñuelas J, Canadell JG, Ogaya R. Increased water-use efficiency during the 20thcentury did not translate into enhanced tree growth. Glob Ecol Biogeogr. 2011;20:597-608.

12. Hu Y, Zhao P, Zhu L, Zhao X, Ni G, Ouyang L, et al. Responses of sap flux and intrinsic water use efficiency to canopy and understory nitrogen addition in a temperate broadleaved deciduous forest. Sci Total Environ. 2019;648:325-36.

13. Magnani F, Mencuccini M, Borghetti M, Berbigier P, Berninger $\mathrm{F}$, Delzon $\mathrm{S}$, et al. The human footprint in the carbon cycle of temperate and boreal forests. Nature. 2007;447:849-51.

14. Thomas RQ, Canham CD, Weathers KC, Goodale CL. Increased tree carbon storage in response to nitrogen deposition in the US. Nat Geosci. 2010;3:13-7.

15. Hietz P, Turner BL, Wanek W, Richter A, Nock CA, Wright SJ. Long-term change in the nitrogen cycle of tropical forests. Science. 2011;334:664-6.

16. Fernández-Martínez $\mathrm{M}$, et al. Atmospheric deposition, $\mathrm{CO}_{2}$, and change in the land carbon sink. Sci Rep. 2017;7(1):6932.
17. Wang R, Goll D, Balkanski Y, Hauglustaine D, Boucher O, Ciais $\mathrm{P}$, et al. Global forest carbon uptake due to nitrogen and phosphorus deposition from 1850 to 2100. Glob Chang Biol. 2017;23: 4854-72.

18. Ollinger SV, et al. Canopy nitrogen, carbon assimilation, and albedo in temperate and boreal forests: Functional relations and potential climate feedbacks. Proc Natl Acad Sci USA (PNAS). 2008;105:19336-41.

19. Guerrieri R, Lepine L, Asbjornsen H, Xiao J, Ollinger SV. Evapotranspiration and water use efficiency in relation to climate and canopy nitrogen in U.S. forests. J Geophys Res Biogeosci. 2016;121:2016JG003415.

20. Galloway JN, Cowling EB. Reactive nitrogen and the world: 200 years of change. Ambio. 2002;31(2):64-71.

21. Bobbink R, Hicks K, Galloway J, Spranger T, Alkemade R, Ashmore $\mathrm{M}$, et al. Global assessment of nitrogen deposition effects on terrestrial plant diversity: a synthesis. Ecol Appl. 2010;20(1):30-59.

22. Dise NB, Ashmore M, Belyazid S, Bleeker A, Bobbink R, de Vries W, et al. Nitrogen as a threat to European terrestrial biodiversity. In: Sutton MA, Howard CM, Erisman JW, Billen G, Bleeker A, Grennfelt P, van Grinsven H, Grizzetti B, editors. The European nitrogen assessment sources, effects, and policy perspectives. Cambridge: Cambridge University Press; 2011. p. 463-94.

23. Cui S, Shi Y, Groffman PM, Schlesinger WH, Zhu YG. Centennial-scale analysis of the creation and fate of reactive nitrogen in China (1910-2010). Proc Natl Acad Sci U S A. 2013;110(6):2052-7.

24. Peñuelas J, Poulter B, Sardans J, Ciais P, van der Velde M, Bopp L, et al. Human-induced nitrogen-phosphorus imbalances alter natural and managed ecosystems across the globe. Nat Commun. 2013;4:2934.

25. Prescott CE. The influence of the forest canopy on nutrient cycling. Tree Physiol. 2002;22:1193-200.

26. Galloway JN, Dentener FJ, Capone DG, Boyer EW, Howarth RW, Seitzinger SP, et al. Nitrogen cycles: past, present, and future. Biogeo- Chem. 2004;70:153-226.

27. Fowler D, Coyle M, Skiba U, Sutton MA, Cape JN, Reis S, et al. The global nitrogen cycle in the twenty-first century. Philos Trans R Soc B. 2013;368:20130164.

28. Tian $\mathrm{H}, \mathrm{Xu}$ R, Canadell JG, Thompson RL, Winiwarter W, Suntharalingam $\mathrm{P}$, et al. A comprehensive quantification of global nitrous oxide sources and sinks. Nature. 2020;586:248-56.

29. Behera SN, Sharma M, Aneja VP, Balasubramanian R. Ammonia in the atmosphere: a review on emission sources, atmospheric chemistry and deposition on terrestrial bodies. Environ Sci Pollut Res. 2013;20:8092-131.

30. Erisman JW, Galloway JN, Seitzinger S, Bleeker A, Dise NB, Petrescu AMR, et al. Consequences of human modification of the global nitrogen cycle. Philos Trans R Soc B. 2013;368: 20130116

31.• Ossohou M, Galy-Lacaux C, Yoboué V, Hickman JE, Gardrat E, Adon $\mathrm{M}$, et al. Trends and seasonal variability of atmospheric $\mathrm{NO}_{2}$ and $\mathrm{HNO}_{3}$ concentrations across three major African biomes inferred from long-term series of ground-based and satellite measurements. Atmos Environ. 2019;207:148-66 This study provides novel data quantifying atmospheric nitrogen deposition in Africa and exploring their temporal trends.

32. Lajtha K, Jones J. Trends in cation, nitrogen, sulfate and hydrogen ion concentrations in precipitation in the United States and Europe from 1978 to 2010: a new look at an old problem. Biogeochemistry. 2013;116:303-34.

33. Waldner P, Marchetto A, Thimonier A, Schmitt M, Rogora M, Granke O, et al. Detection of temporal trends in atmospheric 
deposition of inorganic nitrogen and sulphate to forests in Europe. Atmos Environ. 2014;95:363-74.

34. Bobbink R, Hettelingh J-P. Review and revision of empirical critical loads and dose-response relationships: Proceedings of an expert workshop, Noordwijkerhout, 23-25 June 2010. (Report 680359002/2011). Bilthoven, the Netherlands: Coordination Centre for Effects, National Institute for Public Health and the Environment. 2011.

35.• Ponette-González A, Perroni Y, Weathers KC, De Souza P, Garcia-Oliva F, De Mello WZ. Nitrogen cycling in tropical Atlantic Forest differing in exposure to urban atmospheric nitrogen deposition. Plant Soil. 2017;420:451-65 Important study showing the contribution of pollution from the megacity of Rio de Janeiro to increasing atmospheric nitrogen input and altering dynamics of nitrogen fluxes in the tropical Atlantic Forest.

36. Decina SM, Templer PH, Hutyra LR. Atmospheric Inputs of Nitrogen, Carbon, and Phosphorus across an Urban Area: Unaccounted Fluxes and Canopy Influences. Earth's Future. 2018;6:134-48 This study contributes to improving our understanding on seasonal changes in nitrogen fluxes in urban forests, showing the greater contribution of organic nitrogen to total nitrogen deposition and highlighting the role of tree canopies as source of nutrients to urban waterways through runoff.

37. Fenn ME, Poth MA. Monitoring nitrogen deposition in throughfall using ion exchange resin columns. J Environ Qual. 2004;33:2007-14.

38. Templer PH, Weathers KC. Use of mixed ion exchange resin and the denitrifier method to determine isotopic values of nitrate in atmospheric deposition and canopy throughfall. Atmos Environ. 2011;45:2017-20.

39.• García-Gómez H, et al. Atmospheric deposition of inorganic nitrogen in Spanish forests of Quercus ilex measured with ionexchange resins and conventional collectors. Environ Pollut. 2016;216:653-61 The study is very important because i) it provides data on nitrogen fluxes in forest ecosystems in the Mediterranean basin (less studies compared to other European forest ecosystems), and it compares two methodological approaches in quantifying nitrogen fluxes (bulk deposition and throughfall collectors vs. ion exchange resins).

40. Sheng W, Yu G, Jiang C, Yan J, Liu Y, Wang S, et al. Monitoring nitrogen deposition in typical forest ecosystems along a large transect in China. Environ Monit Assess. 2013;185:833-44.

41. Fenn ME, Bytnerowicz A, Schilling SL. Passive monitoring techniques for evaluating atmospheric ozone and nitrogen exposure and deposition to California ecosystems. Gen. Tech. Rep. PSWGTR-257. Albany: U.S. Department of Agriculture, Forest Service, Pacific Southwest Research Station; 2018. p. 129.

42. Pan YP, Wang YS, Tang GQ, Wu D. Wet and dry deposition of atmospheric nitrogen at ten sites in Northern China. Atmos Chem Phys. 2012;12:6515-35.

43. Li Y, Schichtel BA, Walker JT, Schwede DB, Chen X, Lehmann $\mathrm{CMB}$, et al. Increasing importance of deposition of reduced nitrogen in the United States. Proc Natl Acad Sci. 2016;113:5874-9.

44. Ochoa-Hueso R, Munzi S, Alonso R, Arróniz-Crespo M, Avila A, Bermejo V, et al. Ecological impacts of atmospheric pollution and interactions with climate change in terrestrial ecosystems of the Mediterranean Basin: current research and future directions. Environ Pollut. 2017;227:194-206.

45. Walker JT, Beachley G, Amos HM, Baron JS, Bash J, Baumgardner R, et al. Toward the improvement of total nitrogen deposition budgets in the United States. Sci Total Environ. 2019a;691:1328-52.

46. Flechard CR, Nemitz E, Smith RI, Fowler D, Vermeulen AT, Bleeker A, et al. Dry deposition of reactive nitrogen to European ecosystems: a comparison of inferential models across the NitroEurope network. Atmos Chem Phys. 2010;11:2703-28.

47. Tang SY, et al. Pan-European rural monitoring network shows dominance of $\mathrm{NH}_{3}$ gas and $\mathrm{NH}_{4} \mathrm{NO}_{3}$ aerosol in inorganic atmospheric pollution load. Atmos Chem Phys. 2021;21:875-914.

48. Thimonier A, Kosonen Z, Braun S, Rihm B, Schleppi P, Schmitt $\mathrm{M}$, et al. Total deposition of nitrogen in Swiss forests: comparison of assessment methods and evaluation of changes over two decades. Atmos Environ. 2019;198:335-50 This study provides a relevant comparison among the different approaches used to estimate dry nitrogen deposition, which were applied across different forest sites in Switzerland.

49. Fowler D, Cape JN, Coyle M, Flechard C, Kuylenstierna J, Hicks K, et al. The Global Exposure of Forests to Air Pollutants. Water Air Soil Pollut. 1999;116:5-32.

50. Sutton MA, Tang YS, Miners B, Fowler D. A new diffusion denuder system for long-term, regional monitoring of atmospheric ammonia and ammonium. Water Air Soil Pollut Focus. 2001;1: $145 \mathrm{e} 156$

51. Sutton MA, Nemitz E, Erisman JW, Beier C, Bahl KB, Cellier P, et al. Challenges in quantifying biosphere-atmosphere exchange of nitrogen species. Environ Pollut. 2007;150(1):125-39.

52. Staelens J, Houle D, De Schrijver A, Neirynck J, Verheyen K. Calculating dry deposition and canopy exchange with the canopy budget model: review of assumptions and application to two deciduous forests. Water Air Soil Pollut. 2008;191:149-69.

53. Famulari D, Fowler D, Hargreaves K, Milford C, Nemitz E, Sutton M, et al. Measuring eddy covariance fluxes of ammonia using tunable diode laser absorption spectroscopy. Water Air Soil Pollut Focus. 2005;4(6):151e158.

54. Hansen K, Pryor SC, Boegh E, Hornsby KE, Sørensen LL. Background concen- trations and fluxes of atmospheric ammonia over a deciduous forest. Agric For Meteorol. 2015;214-215:380 92.

55. Geddes JA, Murphy JG. Observations of reactive nitrogen oxide fluxes by eddy covariance above two mid latitude North American mixed hardwood forests. Atmos Chem Phys. 2014;14:2939-57.

56. Wintjen P, Schrader F, Schaap M, Beudert B, Brümmer C. Forestatmosphere exchange of reactive nitrogen in a low polluted areatemporal dynamics and annual budgets. https://doi.org/10.5194/ bg-2020-364 Preprint. Discussion started: 14 October 2020

57. Simpson D, Benedictow A, Berge H, Bergström R, Emberson LD, Fagerli H, et al. The EMEP MSC-W chemical transport modeltechnical description. Atmos Chem Phys. 2012;12:7825-65.

58. Crippa M, et al. High resolution temporal profiles in the Emissions Database for Global Atmospheric Research. Sci Data. 2020;7:121. https://doi.org/10.1038/s41597-020-0462-2.

59. Duncan BN, et al. Satellite data of atmospheric pollution for U.S. air quality applications: examples of applications, summary of data end-user resources, answers to FAQs, and common mistakes to avoid. Atmos Environ. 2014;94:647e662.

60. Levelt PF, Joiner J, Tamminen J, Veefkind JP, Bhartia PK, Stein Zweers DC, et al. The Ozone Monitoring Instrument: overview of 14 years in space. Atmos Chem Phys. 2018;18:5699-745.

61. Manders AMM, Builtjes PJH, Curier L, Denier van der Gon HAC, Hendriks C, Jonkers S, et al. Curriculum vitae of the LOTOSEUROS (v2.0) chemistry transport model, Geosci. Model Dev. 2017;10:4145-73.

62. Theobald MR, Vivanco MG, Aas W, Andersson C, Ciarelli G, Couvidat F, et al. An evaluation of European nitrogen and sulfur wet deposition and their trends estimated by six chemistry transport models for the period 1990-2010. Atmos Chem Phys. 2019;19:379-405.

63. Dentener F, et al. Nitrogen and sulfur deposition on regional and global scales: a multimodel evaluation. Glob Biogeochem Cycles. 2006;20:GB4003. 
64. Vet R, Artz RS, Carou S, Shaw M, Ro CU, Aas W, et al. A global assessment of precipitation chemistry and deposition of sulfur, nitrogen, sea salt, base cations, organic acids, acidity and $\mathrm{pH}$, and phosphorus. Atmos Environ. 2014;93:3-10.

65. Liu L, Zhang X, Xu W, Liu X, Lu X, Wei J, et al. Reviewing global estimates of surface reactive nitrogen concentration and deposition using satellite retrievals. Atmos Chem Phys. 2020;20: 8641-58 This is an excellent overview regarding estimates of nitrogen deposition from remote sensing approach.

66. Vanguelova E, et al. Chemical fluxes in time through forest ecosystems in the UK - Soil response to pollution recovery. Environ Pollut. 2010;158:1857-69.

67. Cape JN, Tang YS, González-Ben\&amp;iacute;ez JM, Mitošinková M, Makkonen U, Jocher M, et al. Organic nitrogen in precipitation across Europe. Biogeosciences. 2012;9:4401-9.

68. Verstraeten A, Verschelde P, De Vos B, Neirynck J, Cools N, Roskams $\mathrm{P}$, et al. Increasing trends of dissolved organic nitrogen (DON) in temperate forests under recovery from acidification in Flanders, Belgium. SciTotal Environ. 2016;553:107-19 Relevant study providing quantifying dissolved organic nitrogen in forests and sources.

69. Neff JC, Holland EA, Dentener FJ, McDowell WH, Russell KM. The origin, composition and rates of organic nitrogen deposition: a missing piece of the nitrogen cycle? Biogeochemistry. 2002;57: 99-136.

70. Izquieta-Rojano S, García-Gomez H, Aguillaume L, Santamaría JM, Tang YS, Santamaría C, et al. Throughfall and bulk deposition of dissolved organic nitrogen to holm oak forests in the Iberian Peninsula: flux estimation and identification of potential sources. Environ Pollut. 2016;210:104-12.

71. Kanakidou M, Myriokefalitakis S, Daskalakis N, Fanourgakis G, Nenes A, Baker AR, et al. Past, Present and Future Atmospheric Nitrogen Deposition. J Atmos Sci. 2016;73(5):2039-47.

72. Schlesinger WH. On the fate of anthropogenic nitrogen. Proc Natl Acad Sci U S A. 2009;106:203-8.

73. Ackerman D, Millet DB, Chen X. Global estimates of inorganic nitrogen deposition across four decades. Glob Biogeochem Cycles. 2019;33:100-7.

74.•• Decina S, Hutyra LR, Templer PH. Hotspots of nitrogen deposition in the world's urban areas: a global data synthesis. Front Ecol Environ. 2020;18(2):92-100 This study is the first to quantify atmospheric nitrogen deposition in urban systems at global scale, by synthesizing data from 174 studies in the literature.

75. Fenn ME, Bytnerowicz A, Schilling SL, Vallano DM, Zavaleta ES, Weiss SB, et al. On-road emissions of ammonia: an underappreciated source of atmospheric nitrogen deposition. Sci Total Environ. 2018;625:909-19.

76. Bishop GA, Stedman DH. Reactive nitrogen species emission trends in three light-/medium-duty United States fleets. Environ Sci Technol. 2015;49:11234-40.

77. Thiruvengadam A, Besch M, Carder D, Oshinuga A, Pasek R, Hogo $\mathrm{H}$, et al. Unregulated greenhouse gas and ammonia emissions from current technology heavy-duty vehicles. J Air Waste Manage Assoc. 2016;66:1045-60.

78. Sutton MA, et al.. Our Nutrient World: the challenge to produce more food and energy with less pollution. Global overview of nutrient management. Centre for ecology and hydrology, Edinburgh on behalf of the Global Partnership on Nutrient Management and the International Nitrogen Initiative. 2013.

79. Liu XJ, et al. Enhanced nitrogen deposition over China. Nature. 2013;494:459-62.

80. Chen Y, Randerson JT, Van Der Werf GR, Morton DC, Mu M, Kasibhatla PS. Nitrogen deposition in tropical forests from savanna and deforestation fires: fire effects on tropical $n$ fluxes. Glob Chang Biol. 2010;16:2024-38.
81. Galy-Lacaux C, Delon C. Nitrogen emission and deposition budget in west and central Africa. Environ Res Lett. 2014;9:125002.

82. Emmett BA, Kjonaas OJ, Gundersen P, Koopmans C, Tietema A, Sleep D. Natural abundance of ${ }^{15} \mathrm{~N}$ in forests across a nitrogen deposition gradient. For Ecol Manag. 1998;101:9-18.

83. Nadelhoffer KJ, Emmett BA, Gundersen P, Kjønaas OJ, Koopmans CJ, Schleppi P, et al. Nitrogen deposition makes a minor contribution to carbon sequestration in temperate forests. Nature. 1999;398:145-8.

84. Gurmesa GA, Lu X, Gundersen P, Mao Q, Zhou K, Fang Y, et al. High retention of ${ }^{15} \mathrm{~N}$-labeled nitrogen deposition in a nitrogen saturated old-growth tropical forest. Glob Chang Biol. 2016;22: 3608-20.

85. Templer PH, Mack MC III, F SC, Christenson LM, Compton JE, Crook HD, et al. Sinks for nitrogen inputs in terrestrial ecosystems: a meta-analysis of enriched ${ }^{15} \mathrm{~N}$ field tracer studies. Ecology. 2012;93:1816-29.

86. Magill AH, Aber JD, Currie WS, Nadelhoffer KJ, Martin ME, McDowell WH, et al. Ecosystem response to 15 years of chronic nitrogen additions at the Harvard Forest LTER, Massachusetts. USA For Ecol Manag. 2004;196:7-28.

87. Schleppi P, Curtaz F, Krause K. Nitrate leaching from a sub-alpine coniferous forest subjected to experimentally increased $\mathrm{N}$ deposition for 20 years, and effects of tree girdling and felling. Biogeochemistry. 2017;134:319-35.

88. Moldan F, Jutterström SEAK, Hruska J, Wright RF. Experimental addition of nitrogen to a whole forest ecosystem at Gårdsjön, Sweden (NITREX): nitrate leaching during 26 years of treatment. Environ Pollut. 2018;242:367-74.

89. Wang JJ, Bowden RD, Lajtha K, Washko SE, Wurzbacher SJ, Simpson MJ. Long-term nitrogen addition suppresses microbial degradation, enhances soil carbon storage, and alters the molecular composition of soil organic matter. Biogeochemistry. 2019;142: 299-313.

90. Frey SD, Ollinger S, Nadelhoffer K, Bowden R, Brzostek E, Burton A, et al. Chronic nitrogen additions suppress decomposition and sequester soil carbon in temperate forests. Biogeochemistry. 2014;121:305-16.

91. Högberg P, Johannisson C, Högberg MN. Is the high ${ }^{15} \mathrm{~N}$ natural abundance of trees in N-loaded forests caused by an internal ecosystem $\mathrm{N}$ isotope redistribution or a change in the ecosystem $\mathrm{N}$ isotope mass balance? Biogeochemistry. 2014;117:351-8.

92. Sheppard LJ, Crossley A, Harvey FJ, Skiba U, Coward P, Ingleby $\mathrm{K}$. Effects of five years of frequent $\mathrm{N}$ additions, with or without acidity, on the growth and below-ground dynamics of a young Sitka spruce stand growing on an acid peat: implications for sustainability. Hydrol Earth Syst Sci. 2004;8:377-91.

93. Gaige E, Dail DB, Hollinger DY, Davidson EA, Fernandez IJ, Sievering H, et al. (2007). Changes in canopy processes following whole-forest canopy nitrogen fertilization of a mature spruceHemlock forest. Ecosystems. 2007;10:1133-47.

93.• Dail DB, Hollinger DY, Davidson EA, Fernandez I, Sievering HC, Scott NA, et al. Distribution of nitrogen-15 tracers applied to the canopy of a mature spruce- hemlock stand, Howland, Maine, USA. Oecologia. 2009;160:589-99 This study reported very important results in terms of species-specific canopy nitrogen retention and foliar uptake, followed an aerial nitrogen manipulation experiment over tree canopies.

95. Giammarchi F, Panzacchi P, Ventura M, Tonon G. Tree growth and water-Use efficiency do not react in the short term to artificially increased nitrogen deposition. Forests. 2020;11:47.

96. Zhang W, et al. CAN canopy addition of nitrogen better illustrate the effect of atmospheric nitrogen deposition on forest ecosystem? Sci Rep. 2015;5:11245 Study providing details on two of the few manipulation experiments where canopy and soil nitrogen additions in forests have been carried out since 2013. 
97. Fernandez IJ, Rustad LE, Norton SA, Kahl JS, Cosby BJ. Experimental acidification causes soil base-cation depletion at the Bear Brook watershed in Maine. Soil Sci Soc Am J. 2003;67:1909-19.

98. Adams M, Kochenderfer J, Edwards P. The Fernow Watershed acidification study: ecosystem acidification, nitrogen saturation and base cation leaching. Water Air Soil Pollut. 2007;7:267-73.

99. De Barba D, Rossi S, Deslauriers A, Morin H. Effects of soil warming on nitrogen foliar applications on bud burst of black spruce. Trees. 2016;30:87-97.

100. Sheppard LJ, Crossley A, Ingleby K, Woods C. Implications of acidified $\mathrm{S}$ inputs on the fate and consequences of $\mathrm{N}$ deposition: results from a field manipulation of a Sitka spruce canopy in southern Scotland. Int J Environ Stud. 2008;65:409-30.

101. Cape JN, Dunster A, Crossley A, Sheppard LJ, Harvey FJ. Throughfall, chemistry in a Sitka spruce plantation in response to six different simulated polluted mist treatments. Water Air Soil Pollut. 2001;130:619-24.

102. Chiwa M, Crossley A, Sheppard LJ, Sakugawa H, Cape JN. Throughfall chemistry and canopy interactions in a Sitka spruce plantation sprayed with six different simulated polluted mist treatments. Environ Pollut. 2004;127:57-64.

103. Liu T, Mao P, Shi L, Eisenhauer N, Liu S, Wang X, et al. Forest canopy maintains the soil community composition under elevated nitrogen deposition. Soil Biol Biochem. 2020;143:107733.

104. Cape JN, Sheppard LJ, Crossley A, van Dijk N, Tang YS. Experimental field estimation of organic nitrogen formation in tree canopies. Environ Pollut. 2010;158:2926-33.

105. Craine JM, Brookshire ENJ, Cramer MD, Hasselquist NJ, Koba $\mathrm{K}$, Marin-Spiotta E, et al. Ecological interpretations of nitrogen isotope ratios of terrestrial plants and soils. Plant Soil. 2015;396(1-2):1-26.

106. Ferretti M, Marchetto A, Arisci S, Bussotti F, Calderisi M, Carnicelli S, et al. On the tracks of Nitrogen deposition effects on temperate forests at their Southern European range - an observational study from Italy. Glob Chang Biol. 2014;20:3423-38.

107. Griffith KT, Ponette-González AG, Curran LM, Weathers KC. Assessing the influence of topography and canopy structure on Douglas fir throughfall with LiDAR and empirical data in the Santa Cruz mountains, USA. Environ Monit Assess. 2015;187: 270 .

108. Hoffman AS, Albeke SE, McMurray JA, Evans RD, Williams DG. Nitrogen deposition sources and patterns in the Greater Yellowstone Ecosystem determined from ion exchange resin collectors, lichens, and isotopes. Sci Total Environ. 2019;683:709 18.

109. Pierret MC, Viville D, Dambrine E, Cotel S, Probst A. Twentyfive years record of chemicals in open field precipitation and throughfalls from a medium altitude forest catchment Strengbach- NE France: an obvious response to atmospheric pollution trend. Atmos Environ. 2019;202:296-314.

110. Fenn ME, Ross CS, Schilling SL, Baccus WD, Larrabee MA, Lofgren RA. Atmospheric deposition of nitrogen and sulfur and preferential canopy consumption of nitrate in forests of the Pacific Northwest, USA. For Ecol Manag. 2013;302:240-53.

111. Templer PH, Weathers KC, Lindsey A, Lenoir K, Scott L. Atmospheric inputs and nitrogen saturation status in and adjacent to Class I wilderness areas of the northeastern US. Oecologia. 2015a; $177: 5-15$.

112. Lindberg SE, Lovett GM, Richter DD, Johnson DW. Atmospheric deposition and canopy interactions of major ions in a forest. Science. 1986;231:141-5.

113. Mustajärvi K, Merilä P, Derome J, Lindroos A-J, Helmisaari H-S, Nöjd P, et al. Fluxes of dissolved organic and inorganic nitrogen in relation to stand characteristics and latitude in Scots pine and
Norway spruce stands in Finland. Boreal Environ Res. 2008;13(Suppl. B):3-21.

114. Ponette-González AG, Weathers KC, Curran LM. Tropical landcover change alters biogeochemical inputs to ecosystems in a Mexican montane landscape. Ecol Appl. 2010;20(7):1820-37.

115. Umana NH-N, Wanek W. Large Canopy Exchange Fluxes of Inorganic and Organic Nitrogen and Preferential Retention of Nitrogen by Epiphytes in a Tropical Lowland Rainforest. Ecosystems. 2010;13:367-81.

116. Woods CL, Hunt SL, Morris DM, Gordon AM. Epiphytes influence the transformation of nitrogen in coniferous forest canopies. Boreal Environ Res. 2012;17:411-24.

117.• Houle D, Marty C, Duchesne L. Response of canopy nitrogen uptake to a rapid decrease in bulk nitrate deposition in two eastern Canadian boreal forests. Oecologia. 2015;177:29-37 Important study providing experimental evidences of relationship between canopy nitrogen retention and nitrogen deposition.

118. Van Langenhove L, et al. Atmospheric deposition of elements and its relevance for nutrient budgets of tropical forests. Biogeochemistry. 2020;149:175-93.

119. Sparks JP. Ecological ramifications of the direct foliar uptake of nitrogen. Oecologia. 2009;159:1-13.

120. Adriaenssens $\mathrm{S}$, et al. Foliar nitrogen uptake from wet deposition and the relation with leaf wettability and water storage capacity. Water Air Soil Pollut. 2012a;219:43-57.

121. Schwarz TM, et al. More efficient aboveground nitrogen use in more diverse Central European forest canopies. For Ecol Manag. 2014;313:274-82.

122. Avila A, Aguillaume L, Izquieta-Rojano S, García-Gómez H, Elustondo D, Santamaría JM, et al. Quantitative study on nitrogen deposition and canopy retention in Mediterranean evergreen forests. Environ Sci Pollut Res. 2017;24:26213-26 Important data regarding nitrogen deposition and interactions with tree canopies in the understudied Mediterranean forest ecosystems.

123. Lovett GM, Lindberg SE. Atmospheric deposition and canopy interactions of nitrogen in forests. Can J For Res. 1993;23:160316.

124. Wexler SK, Goodale CL, McGuire KJ, Bailey SW, Groffman PM. Isotopic signals of summer denitrification in a Northern hardwood forested catchment. Proc Nat Acad Sci - PNAS. 2014;111(46): 16413-8.

125. Fang Y, Koba K, Makabe A, Takahashi C, Zhu W, Hayashi T, et al. Microbial denitrification dominates nitrate losses from forest ecosystems. Proc Natl Acad Sci. 2015;112(5):1470-4.

126. Adriaenssens S, Staelens J, Wuyts K, Samson R, Verheyen K, Boeckx P. Retention of dissolved inorganic nitrogen by foliage and twigs of four temperate tree species. Ecosystems. 2012b;15: 1093-107.

127. Coble AA, Hart SC. The significance of atmospheric nutrient inputs and canopy interception of precipitation during ecosystem development in piñone juniper woodlands of the southwestern USA. J Arid Environ. 2013;98:79e87.

128. Van Stan JT, Stubbins A. Tree-DOM: Dissolved organic matter in throughfall and stemflow. Limnol Oceanogr. 2018;3:199-214.

129. Ward ND, et al. Editorial: Integrative Research on Organic Matter Cycling across Aquatic Gradients. Front Mar Sci. 2017;4:131.

130. Tomaszewski T, Boyce RL, Sievering H. Canopy uptake of atmospheric nitrogen and new growth nitrogen requirement at a Colorado subalpine forest. Can J For Res. 2003;33:2221-7.

131. Le Mellec A, Meesenburg H, Michalzik B. The importance of canopy-derived dissolved and particulate organic matter (DOM and POM) - comparing throughfall solution from broadleaved and coniferous forests. Ann For Sci. 2010;67:411.

132. Hunter MD. Insect population dynamics meets ecosystem ecology: effects of herbivory on soil nutrient dynamics. Agric For Entomol. 2001;3:77-84. 
133.• Bittar TB, Pound P, Whitetree A, Moore LD, Van Stan JT II. Estimation of throughfall and stemflow bacterial flux in a subtropical oak-cedar forest. Geophys Res Lett. 2018;45(3):1410-8 This study provides novel data on bacterial fluxes from the phyllosphere to the pedosphere, as it showed that throughfall fluxes are not only relevant for the water and nutrients they carry, but also microbial communities.

134. Pitman RM, Vanguelova EI, Benham SE. The effects of phytophagous insects on water and soil nutrient concentrations and fluxes through forest stands of the Level II monitoring network in the UK. Sci Total Environ. 2010;409(1):169-81.

135. Schwendenmann L, Michalzik B. Dissolved and particulate carbon and nitrogen fluxes along a Phytophthora agathidicida infection gradient in a kauri (Agathis australis) dominated forest. Fungal Ecol. 2019;42:100861.

135. Jactel H, Koricheva J, Castagneyrol B. Responses of forest insect pests to climate change: Not so simple. Curr Opin Insect Sci. 2019;35:103-8

137.• Templer PH, Weathers KC, Ewing HA, Dawson TE, Mambelli S, Lindsey AM, et al. Fog as a source of nitrogen for redwood trees: evidence from fluxes and stable isotopes. J Ecol. 2015b;103: 1397-407 This study provides novel evidences of the ecological relevance of fog as source of nitrogen, including foliar nitrogen uptake.

138. Wuyts K, Adriaenssens S, Staelens J, Wuytack Wittenberghe SV, Boeckx P, Samson R, et al. Contributing factors in foliar uptake of dissolved inorganic nitrogen at leaf level. Sci Total Environ. 2015;505:992-1002 Study providing important data on foliar nitrogen uptake from a manipulation experiments on potted plants.

139.• Nair RK, Perks MP, Weatherall A, Baggs EM, Mencuccini M. Does canopy nitrogen uptake enhance carbon sequestration by trees? Glob Chang Biol. 2016;22:875-88 Novel study quantifying the foliar nitrogen uptake by carrying out a manipulation experiments (including both soil and canopy nitrogen fertilizations) on a mesocosm.

139.• Bourgeois I, Clément JC, Caillon N, Savarino J. Foliar uptake of atmospheric nitrate by two dominant subalpine plants: insights from in situ triple-isotope analysis. New Phytol. 2019;223(4): 1784-94 This study provides evidence of in situ foliar nitrogen uptake by using the triple isotope approach in nitrate, with particular reference to $\Delta^{17} \mathrm{O}$.

141. Wang X, Wang B, Wang C, Wang Z, Li J, Jia Z, et al. Canopy processing of $\mathrm{N}$ deposition increases short-term leaf $\mathrm{N}$ uptake and photosynthesis, but not long-term $\mathrm{N}$ retention for aspen seedlings. New Phytol. 2021;229:2601-10.

142. Gottlieb TR, Eckardt FD, Venter ZS, Cramer MD. The contribution of fog to water and nutrient supply to Arthraerua leubnitziae in the central Namib Desert, Namibia. J Arid Environ. 2019;161: 35-46 This study highlights the ecological relevance of fog as source of water but also nitrogen and it demonstrate the occurrence of foliar and stem nitrogen uptake.

143. Sparks JP, Monson RK, Sparks KL, Lerdau M. Leaf uptake of nitrogen dioxide $\left(\mathrm{NO}_{2}\right)$ in a tropical wet forest: implication for tropospheric chemistry. Oecologia. 2001;127:214-21 Seminal paper on processes underpinning foliar nitrogen uptake.

144. Krupa SV. Effects of atmospheric ammonia $\left(\mathrm{NH}_{3}\right)$ on terrestrial vegetation: a review. Environ Pollut. 2003;124:179-221.

145. Hu YB, Fernández V, Ma L. Nitrate transporters in leaves and their potential roles in foliar uptake of nitrogen dioxide. Front Plant Sci. 2014;5:360.

146. Sparks JP, Roberts JM, Monson RK. The uptake of gaseous organic nitrogen by leaves: a significant global nitrogen transfer process. Geophys Res Lett. 2003;30(23):2189.
147. Lockwood AL, Filley TR, Rhodes D, Shepson PB. Foliar uptake of atmospheric organic nitrates. Geophys Res Lett. 2008;35: L15809.

148. Siegwolf RTW, Matyssek R, Saurer M, Maurer S, GunthardtGoerg MS, Schmutz P, et al. Stable isotope analysis reveals differential effects of soil nitrogen and nitrogen dioxide on the water use efficiency in hybrid poplar leaves. New Phytol. 2001;149: 233-46.

149.• Liu N, Wu SH, Guo QF, Wang JX, Cao C, Wang J. Leaf nitrogen assimilation and partitioning differ among subtropical forest plants in response to canopy addition of nitrogen treatments. Sci Total Environ. 2018;637-638:1026-34 Important results from a canopy nitrogen manipulation experiment in a subtropical forest in China reporting on leaf nitrogen retention, assimilation and its effects on photosynthesis, by exploring also differences among the dominant tree species.

150. Amman M, Siegwolf RTW, Pichelmayer F, Suter M, Saurer M, Brunold C. Estimating the uptake of traffic derived NO2 form $15 \mathrm{~N}$ abundance in needles of Norway spruce. Oecologia. 1999;118: 124-31.

151. Vallano DM, Sparks JP. Foliar $\delta^{15} \mathrm{~N}$ values as indicators of foliar uptake of atmospheric nitrogen pollution. In: Dawson TE, Siegwolf TW, editors. Stable isotopes as indicators of ecological change. New York.: Academic Press; 2007. p. 93-109.

152. Guerrieri MR, Siegwolf RTW, Saurer M, Jäggi M, Cherubini P, Ripullone F, et al. Impact of different nitrogen emission sources on tree physiology as assessed by a triple stable isotope approach. Atmos Environ. 2009;43:410-8.

153. Savard MM. Tree-ring stable isotopes and historical perspectives on pollution — an overview. Environ Pollut. 2010;158:2007-13.

154. Gerhart LM, Mclauchlan KK. Reconstructing terrestrial nutrient cycling using stable nitrogen isotopes in wood. Biogeochemistry. 2014;120:1-21.

155. Liu X-Y, Koba K, Makabe A, Liu C-Q. Nitrate dynamics in natural plants: insights based on the concentration and natural isotope abundances of tissue nitrate. Front Plant Sci. 2014;5:355.

156. Liu XY, Koba K, Yoh M, Liu CQ. Nitrogen and oxygen isotope effects of tissue nitrate associated with nitrate acquisition and utilization in the moss Hypnum plumaeforme. Funct Plant Biol. 2012;39:598-608.

157.• Liu X-Y, et al. Nitrate is an important nitrogen source for Arctic tundra plants. Proc Natl Acad Sci. 2018;115:3398-403 This study published novel results on the occurrence of nitrate uptake by tundra plants and stable isotopes data, including $\Delta{ }^{17} \mathrm{O}$ helping to explore sources of nitrate.

158. Adriaenssens S, Staelens J, Baeten L, Verstraeten A, Boeckx P, Samson R, et al. Influence of canopy budget model approaches on atmospheric deposition estimates to forests. Biogeochemistry. 2013;116:215-29.

159. Heaton THE. ${ }^{15} \mathrm{~N} /{ }^{14} \mathrm{~N}$ ratios of nitrate and ammonium in rain at Pretoria, South Africa. Atmos Environ. 1987;21:843-52.

160. Kendall C, Elliott EM, Wankel SD. Tracing anthropogenic inputs of nitrogen to ecosystems. In: Stable Isotopes in Ecology and Environmental Science (eds Michener R, Lajtha K). Boston: Blackwell Publishing; 2007. p. 375-449.

161. Felix JD, Elliott EM. Isotopic composition of passively collected nitrogen dioxide emissions: vehicle, soil and livestock source signatures. Atmos Environ. 2014;92:359e366.

162.• Elliott EM, Yu Z, Cole AS, Coughlin JG. Isotopic advances in understanding reactive nitrogen deposition and atmospheric processing. Sci Total Environ. 2019;662:393-403 This is a great review providing useful information on the use of stable isotopes to better understanding sources of atmospheric nitrogen deposition, with particular reference to chemical transformation of reactive nitrogen in the atmosphere. 
163. Heaton THE, Spiro B, Madeline S, Robertson C. Potential canopy influences on the isotopic composition of nitrogen and sulphur in atmospheric deposition. Oecologia. 1997;109:600-7.

164. Savard MM, Bégin C, Smirnoff A, Marion J, Rioux-Paquette E. Tree-ring nitrogen isotopes reflect anthropogenic $\mathrm{NO}_{\mathrm{x}}$ emissions and climatic effects. Environ Sci Technol. 2009;43:604-9.

165.• Guerrieri R, Vanguelova EL, Michalski G, Heaton THE, Mencuccini M. Evidence for the occurrence of biological nitrification and nitrogen deposition processing in forest canopies. Glob Chang Biol. 2015;21:4613-26 By using the triple isotope approach (particularly the $\Delta^{17} \mathrm{O}$ ) in nitrate obtained from rainfall and throughfall this study provide first evidence of nitrification in tree canopies of Scots pine and beech as source of nitrate.

166.• Guerrieri R, Lecha L, Mattana S, Cáliz J, Casamayor EO, Barceló A, et al. Partitioning between atmospheric deposition and canopy microbial nitrification into throughfall nitrate fluxes in a Mediterranean forest. J Ecol. 2020;108(2):626-40 This is the first study showing presence (through metabarcoding and quantitative qPCR analyzes) of nitrifying microbes and their activity (through $\Delta^{17} \mathrm{O}$ in nitrate in rainfall and throughfall fluxes) in transforming atmospheric nitrogen.

167. Högberg P. ${ }^{15} \mathrm{~N}$ natural abundance in soil-plant systems. New Phytol. 1997;137:179-203.

168. Sah SP, Brumme R. Natural ${ }^{15} \mathrm{~N}$ abundance in two nitrogen forest ecosystems at Solling, Germany. J For Sci. 2003;49:515-22.

169. Schwarz MT, Oelmann Y, Wilcke W. Stable N isotope composition of nitrate reflects $\mathrm{N}$ transformations during the passage of water through a montane rain forest in Ecuador. Biogeochemistry. 2014;102:195-208.

170. Mariotti A, Germon JC, Hubert P, Kaiser P, Letolle R, Tardieux $A$, et al. Experimental determination of nitrogen kinetic isotope fractionation: some principles; illustration for the denitrification and nitrification processes. Plant Soil. 1981;62:413-30.

171. Pardo LH, Kendall C, Pett-Ridge J, Chang CCY. Evaluating the source of stream water nitrate using $\delta^{15} \mathrm{~N}$ and $\delta^{18} \mathrm{O}$ in nitrate in two watersheds in New Hampshire, USA. Hydrol Process. 2004;18:2699-712.

172. Yu L, Zhu J, Mulder J, Dörsch P. Multiyear dual nitrate isotope signatures suggest that $\mathrm{N}$-saturated subtropical forested catchments can act as robust $\mathrm{N}$ sinks. Glob Chang Biol. 2016;22: 3662-74.

173.• Sebestyen SD, et al. Unprocessed Atmospheric Nitrate in Waters of the Northern Forest Region in the U.S. and Canada. Environ Sci Technol. 2019;53:3620-33 This study provides important data on the sources of nitrate in different watersheds across North America by using the dual isotope approach $\left(\delta^{15} \mathrm{~N}\right.$ and $\delta^{18} \mathrm{O}$ in nitrate).

174.• Watanabe K, et al. Microbial nitrification in throughfall of a Japanese cedar associated with archaea from the tree canopy. SpringerPlus. 2016;5:1596 First study assessing abundance of nitrifying archaea in the phyllosphere and throughfall water.

175. Mariotti A, Mariotti F, Champigny M-L, Amarger N, Moyse A. Nitrogen Isotope Fractionation Associated with Nitrate Reductase Activity and Uptake of $\mathrm{NO}_{3}{ }^{-}$by Pearl Millet. Plant Physiol. 1982;69(4):880-4.

176. Riha KM, Michalski G, Gallo EL, Lohse KA, Brooks PD, Meixner T. High atmospheric nitrate inputs and nitrogen turnover in semi-arid urban catchments. Ecosystems. 2014;17:1309-25.

177. Michalski G, Savarino J, Bohlke JK, Thiemens M. Determination of the total oxygen isotopic composition of citrate and the Calibration of a $\Delta^{17} \mathrm{O}$ nitrate reference material. Anal Chem. 2002;74:4989-93.

178.• Michalski G, Scott Z, Kabiling M, Thiemens MH. First measurements and modeling of $\Delta^{17} \mathrm{O}$ in atmospheric nitrate. Geophys Res Lett. 2003;30:1870 Important paper on technical and theoretical understanding on $\Delta^{17} \mathrm{O}$ in nitrate and its application in eco-hydrology studies.

179. Costa AW, Michalski G, Schauer AJ, Alexander B, Steig EJ, Shepson PB. Analysis of atmospheric inputs of nitrate to a temperate forest ecosystem from $\Delta^{17} \mathrm{O}$ isotope ratio measurements. Geophys Res Lett. 2011;38:L15805.

180. Michalski G, Bhattacharya SK, Mase DF. Oxygen isotope dynamics of atmospheric nitrate and its precursor molecules. In: Baskaran M, editor. In: Handbook of Environmental Isotope Geochemistry, Advances in Isotope Geochemistry. Berlin, Heidelberg: Springer-Verlag; 2011. p. 613-35.

181.• Rose L, Elliott EM, Adams MB. Triple nitrate isotopes indicate differing nitrate source contributions to streams across a nitrogen saturation gradient. Ecosystems. 2015;18(7):1209-23 Study providing novel data on sources of nitrate (by using stable isotopes, particularly $\Delta^{17} \mathrm{O}$ ) at different watersheds subjected to aerial nitrogen and sulfur spraying - ref. Table 1 .

182. Hundey E, et al. Agriculture causes nitrate fertilization of remote alpine lakes. Nat Commun. 2016;7:10571.

183. Bourgeois I, Savarino J, Caillon N, Angot H, Barbero A, Delbart F, et al. Tracing the Fate of Atmospheric Nitrate in a Subalpine Watershed Using $\Delta^{17}$ O. Environ Sci Technol. 2018;52(10):556170.

184. Nadkarni NM. Epiphyte biomass and nutrient capital of a neotropical elfin forest. Biotropica. 184(16):249-56.

185. Nadkarni NM, et al. Am Zool. 94. 34(1):70-8.

186. van Stan JTII, Pypker TG. A review and evaluation of forest canopy epiphyte roles in the partitioning and chemical alteration of precipitation. Sci Total Environ. 2015;536:813-24.

187. Lindow SE, Brandl MT. Microbiology of the phyllosphere. Appl Environ Microbiol. 2003;69:1875-83.

188. Delmotte N, et al. Community proteogenomics reveals insights into the physiology of phyllosphere bacteria. Proc Nat Acad Sci US Am. 2009;106:16428-33.

189.• Kembel SW, O'connor TK, Arnold HK, Hubbell SP, Wright SJ, Green JL. Relationships between phyllosphere bacterial communities and plant functional traits in a neotropical forest. Proc Natl Acad Sci U S A. 2014;111:13715-20 Important study linking phyllosphere microbes with host tree physiological traits.

190. Vorholt JA. Microbial life in the phyllosphere. Nat Rev Microbiol. 2012;10:828-40.

191. Andrews JH, Harris RF. The ecology and biogeography of microorganisms on plant surfaces. Annu Rev Phytopathol. 2000;38: 145-80.

192. Morris CE, Kinkel LL. Fifty years of phyllosphere microbiology: Significant contributions to research in related fields. In: Lindow SE, Hecht-Poinar EI, Elliott VJ, editors. Phyllosphere Microbiology. St Paul: APS Press; 2002. p. 365-75.

193.• Unterseher M, Siddique AB, Brachmann A, Peršoh D. Diversity and composition of the leaf mycobiome of beech (Fagus sylvatica) are affected by local habitat conditions and leaf biochemistry. PLoS One. 2016;11(4):e0152878 This study reports novel results on leaf mycobiome for one of the most common species in Europe (Fagus sylvatica) and its relationships with leaf pigments and environmental factors.

194. Peñuelas J, Terradas J. The foliar microbiome. Trends Plant Sci. 2014;19(5):278-80.

195.• Vacher C, Hampe A, Porté AJ, Sauer U, Compant S, Morris CE. The phyllosphere: microbial jungle at the plant-climate interface. Annu Rev Ecol Evol Syst. 2016;47:1-24 Very important review on phyllosphere microbes.

196.• Laforest-Lapointe I, Messier C, Kembel SW. Tree phyllosphere bacterial communities: exploring the magnitude of intra- and interindividual variation among host species. PeerJ. 2016;4:e2367 Results of this study contributes to improve our understanding on leaf microbes-host tree interactions by exploring 
differences between tree species in the phyllosphere microbial communities.

197. Copeland JK, Yuan L, Layeghifard M, Wang PW, Guttman DS. Seasonal community succession of the phyllosphere microbiome. Mol Plant-Microbe Interact. 2015;28:274-85.

198. Dees MW, Lysøe E, Nordskog B, Brurberg MB. Bacterial communities associated with surfaces of leafy greens: shift in composition and decrease in richness over time. Appl Environ Microbiol. 2015;81:1530-9.

199.• Gandolfi I, et al. Diversity and hydrocarbon-degrading potential of epiphytic microbial communities on Platanus $\mathrm{x}$ acerifolia leaves in an urban area. Environ Pollut. 2017;220:650-8 This study provides evidences of the role of leaf microbes in processing atmospheric pollutants in urban environment.

200. Aydogan EL, Moser G, Müller C, Kämpfer P, Glaeser SP. LongTerm Warming Shifts the Composition of Bacterial Communities in the Phyllosphere of Galium album in a Permanent Grassland Field-Experiment. Front Microbiol. 2018;9:144.

201. Ren G, Zhu C, Alam MS, Tokida T, Sakai H, Nakamura H, et al. (2015). Response of soil, leaf endosphere and phyllosphere bacterial communities to elevated $\mathrm{CO}_{2}$ and soil temperature in a rice paddy. Plant Soil. 2015;392:27-44.

202. Peñuelas J, Rico L, Ogaya R, Jump AS, Terradas J. Summer season and long-term drought increase the richness of bacteria and fungi in the foliar phyllosphere of Quercus ilex in a mixed Mediterranean forest. Plant Biol (Stuttg). 2012;14(4):565-75.

203. Remus-Emsermann MNP, Schlechter RO. Phyllosphere microbiology: at the interface between microbial individuals and the plant host. New Phytol. 2018;218:1327-33.

204.• Lambais MR, Barrera SE, Santos EC, Crowley DE, Jumpponen A. Phyllosphere metaproteomes of trees from the Brazilian atlantic forest show high levels of functional redundancy. Microb Ecol. 2017;73:123-34 This study providing novel data regarding phyllosphere bacterial composition and their functional role, the latter assessed trough preteomic approach.

205. Reed SC, Cleveland CC, Townsend AR. Functional ecology of free-living nitrogen fixation: a contemporary perspective. Annu Rev Ecol Evol Syst. 2011;42:489-512.

206. Vitousek PM, Menge DNL, Reed SC, Cleveland CC. Biological nitrogen fixation: rates, patterns and ecological controls in terrestrial ecosystems. Philos Trans R Soc B. 2013;368:20130119.

207. Furnkranz M, Wanek W, Richter A, Abell G, Rasche F, Sessitsch A. Nitrogen fixation by phyllosphere bacteria associated with higher plants and their colonizing epiphytes of a tropical lowland rainforest of Costa Rica. ISME J. 2008;2:561-70.

208.• Stanton DE, Batterman SA, Von Fisher JC, Hedin LO. Rapid nitrogen fixation by canopy microbiome in tropical forest determined by both phosphorus and molybdenum. Ecology. 2019;100: e02795 Important study quantifying $\mathbf{N}_{\mathbf{2}}$ fixation by free-living microbes in tree canopies and its relationship with phosphorus availability.

209.• Van Langenhove L, et al. Regulation of nitrogen fixation from free-living organisms in soil and leaf litter of two tropical forests of the Guiana shield. Plant Soil. 2020;450:93-110 Important study quantifying $\mathrm{N}_{2}$ fixation by free-living microbes, particularly those in tree canopies.

$210 . \bullet$ Moreira JCF, et al. Asymbiotic nitrogen fixation in the phyllosphere of the Amazon forest: Changing nitrogen cycle paradigms. Sci Total Environ. 2021;773:145066 Important study quantifying $\mathbf{N}_{2}$ fixation by free-living microbes in tree canopies and its relationship with environmental conditions (particularly drought).

211. Rico L, Ogaya R, Terradas J, Peñuelas J. Community structures of N2-fixing bacteria associated with the phyllosphere of a Holm oak forest and their response to drought. Plant Biol. 2014;16:586-93.
212.• Moyes AB, Kueppers LM, Pett-Ridge J, Carper DL, Vandehey N, O'neil J, et al. Evidence for foliar endophytic nitrogen fixation in a widely distributed subalpine conifer. New Phytol. 2016;210:65768 Novel study using isotopic and metagenomic approaches to demonstrate $\mathbf{N}$ fixation by needle endophyte microbes and its assimilation by plants.

213. Wurzburger N. Old-growth temperate forests harbor hidden nitrogen-fixing bacteria. New Phytol. 2016;210(2):374-6.

214. Lindo Z, Whiteley JA. Old trees contribute bio-available nitrogen through canopy bryophytes. Plant Soil. 2011;342:141-8.

215. Rennenberg $\mathrm{H}$, Gessler $\mathrm{A}$. Consequences of $\mathrm{N}$ deposition to forest ecosystems - recent results and future research needs. Water Air Soil Pollut. 1999;116:47-64.

216. Papen H, Geßler A, Zumbusch E, Rennenberg H. Chemolithoautotrophic nitrifiers in the phyllosphere of a spruce ecosystem receiving high atmospheric nitrogen input. Curr Microbiol. 2002;44:56-60.

217. Cáliz J, Triadó-Margarit X, Camarero L, Casamayor EO. A longterm survey unveils strong seasonal patterns in the airborne microbiome coupled to general and regional atmospheric circulations. Proc Natl Acad Sci U S A. 2018;115(48):12229-34 This study contributes to a better understanding of dynamics of microbial dispersal in relations to origin of air masses.

218.• Teachey ME, Pound P, Ottesen EA, Van Stan JT. Bacterial community composition of throughfall and stemflow. Front For Glob Change. 2018;1:7 Study reporting novel data on composition and structure of bacteria exchanged between the phyllosphere and forest floor through stemflow and throughfall.

219. Reche I, D'Orta G, Mladenov N, Winget DM, Suttle CA. Deposition rates of viruses and bacteria above the atmospheric boundary layer. ISME J. 2018;12:1154-62.

220. Matson AL, Corre MD, Veldkamp E. Nitrogen cycling in canopy soils of tropical montane forests responds rapidly to indirect $\mathrm{N}$ and P fertilization. Glob Chang Biol. 2014;20:3802-13.

221. Jeník J. Root systems of tropical trees. 8. Stilt-roots and allied adaptations. Preslia. 1973;45:250-64.

222. Nadkarni NM, Schaefer DA, Matelson TJ, Solano R. Comparison of arboreal and terrestrial soil characteristics in a lower montane forest, Monteverde, Costa Rica. Pedobiologia. 2002;46:24-33.

223.• Gotsch SG, Nadkarni N, Amici A. The functional roles of epiphytes and arboreal soils in tropical montane cloud forests. J Trop Ecol. 2016;32(5):455-68 This study provides an overview of the ecological role of epiphytic communities of tropical montane cloud forests, including their contribution to soil canopy and nutrient cycling within the tree canopies.

224. Hietz P, Wanek W, Wania R, Nadkarni NM. Nitrogen-15 natural abundance in a montane cloud forest canopy as an indicator of nitrogen cycling and epiphyte nutrition. Oecologia. 2002;131: $350-5$.

225. Cardelús CL. Litter Decomposition Within the Canopy and Forest Floor of Three Tree Species in a Tropical Lowland Rain forest, Costa Rica. Biotropica. 2010;42(3):300-8.

226. Zimmermann A, Wilcke W, Elsenbeer H. Spatial and temporal patterns of throughfall quantity and quality in a tropical montane forest in Ecuador. J Hydrol. 2007;343:80-96.

227. Longino J, Nadkarni N. A comparison of ground and canopy leaf litter ants (Hymenop- tera: Formicidae) in a neotropical montane forest. Psyche. 1990;97:81-94.

228. Rodgers DJ, Kitching RL. Vertical stratification of rainforest collembolan (Collembola: Insecta) assemblages: description of ecological patterns and hypotheses concerning their generation. Ecography. 1998;21(4):392-400.

229. Antoniazzi R, Viana-Junior AB, Pelayo-Martínez J, Ortiz-Lozada L, Neves FS, Leponce M, et al. Distance - decay patterns differ between canopy and ground ant assemblages in a tropical rainforest. J Trop Ecol. 2020;36:234 42. 
230.• van Stan JT, Gutmann E, Friesen J. Precipitation Partitioning by Vegetation. Switzerland: Springer Nature Switzerland AG; 2020. Important book providing a holistic view of water fluxes within forest ecosystems, which includes also microbial life in tree canopies.

231. Hill C. Vegetation: A Sink for Atmospheric Pollutants. J Air Pollut Control Assoc. 1971;21(6):341-6.

232. Delgado-Baquerizo, et al. A global atlas of the dominant bacteria found in soil. Science. 2018;359:320-5.

233. Walker JT, Bell MD, Schwede D, Cole A, Beachley G, Lear G, et al. Aspects of uncertainty in total reactive nitrogen deposition estimates for North American critical load applications. Sci Total Environ. 2019b;10(690):1005-18.

234. Sutton MA, Reis S, Riddick SN, Dragosits U, Nemitz E, Theobald $\mathrm{MR}$, et al. Towards a climate-dependent paradigm of ammonia emission and deposition. Philos Trans R Soc B. 2013;368: 20130166.

235. Hansen K, Personne E, Skjoth CA, Loubet B, Ibrom A, Jensen R, et al. Investigation sources of measured forest-atmospheric ammonia fluxes using tow-layer bi-directional modeling. Agric For Meteorol. 2017;237-238:80-94.

236. Pan Y, Tian S, Wu D, Xu W, Zhu X, Liu C, et al. Ammonia should be considered in field experiments mimicking nitrogen deposition. Atmos Ocean Sci Lett. 2020;13(3):248-51.
237. Sullivan BW, Smith WK, Townsend AR, Nasto MK, Reed SC, Chazdon RL, et al. Spatially robust estimates of biological nitrogen $(\mathrm{N})$ fixation imply substantial human alteration of the tropical N cycle. Proc Natl Acad Sci. 2014;111(22):8101-6.

238. Dezi S, Medlyn B, Tonon G, Magnani F. The effect of nitrogen deposition on forest carbon sequestration: a model-based analysis. Glob Chang Biol. 2010;16:1470-86.

239. Caldararu S, Thum T, Yu L, Zaehle S. Whole-plant optimality predicts changes in leaf nitrogen under variable $\mathrm{CO}_{2}$ and nutrient availability. New Phytol. 2019;225:2331-46.

240.• Rosier CL, Van Stan JT, Moore LD, Schrom JOS, Wu T, Reichard JS, et al. Forest canopy structural controls over throughfall affect soil microbial community structure in an epiphyte-laden maritime oak stand. Ecohydrology. 2015;8: 1459-70 This study provides novel data on the role of tree canopy conditions (including presence of epiphytes) in controlling water and nutrient distribution to forest soils and in affecting soil microbial communities.

241. Shokralla S, Spall JL, Gibson JF, Hajibabaei M. Next-generation sequencing technologies for environmental DNA research. Mol Ecol. 2012;21:1794-805.

Publisher's Note Springer Nature remains neutral with regard to jurisdictional claims in published maps and institutional affiliations. 